\title{
Efficient Regioselective Synthesis of Novel Condensed Sulfur-Nitrogen Heterocyclic Compounds Based on Annulation Reactions of 2-Quinolinesulfenyl Halides with Alkenes and Cycloalkenes
}

\author{
Vladimir A. Potapov*(D), Roman S. Ishigeev (D) and Svetlana V. Amosova (D) \\ A. E. Favorsky Irkutsk Institute of Chemistry, Siberian Division of The Russian Academy of Sciences, \\ 1 Favorsky Str., 664033 Irkutsk, Russia; ishigeev@irioch.irk.ru (R.S.I.); amosova@irioch.irk.ru (S.V.A.) \\ * Correspondence: v_a_potapov@irioch.irk.ru or v.a.potapov@mail.ru; Tel.: +7-3952-426599
}

Citation: Potapov, V.A.;

Ishigeev, R.S.; Amosova, S.V. Efficient Regioselective Synthesis of Novel Condensed Sulfur-Nitrogen

Heterocyclic Compounds Based on Annulation Reactions of

2-Quinolinesulfenyl Halides with Alkenes and Cycloalkenes. Molecules 2021, 26, 4844. https://doi.org/ $10.3390 /$ molecules 26164844

Academic Editors: Oleg A. Rakitin and Andrea Penoni

Received: 30 June 2021

Accepted: 6 August 2021

Published: 10 August 2021

Publisher's Note: MDPI stays neutral with regard to jurisdictional claims in published maps and institutional affiliations.

Copyright: (c) 2021 by the authors. Licensee MDPI, Basel, Switzerland. This article is an open access article distributed under the terms and conditions of the Creative Commons Attribution (CC BY) license (https:/ / creativecommons.org/licenses/by/ $4.0 /)$.

\begin{abstract}
The preparation of novel reagents 2-quinolinesulfenyl chloride and bromide based on available 2-mercaptoquinoline has been described. This approach opens up opportunities for the introduction of 2-quinolinesulfenyl chloride and bromide into organic synthesis. Regioselective synthesis of novel 1,2-dihydro[1,3]thiazolo[3,2-a]quinolin-10-ium derivatives in high yields has been developed by annulation reactions of 2-quinolinesulfenyl chloride and bromide with alkenes. Condensed tetracyclic products have been obtained by the reactions of 2-quinolinesulfenyl chloride and bromide with cycloalkenes. The opposite regiochemistry in the reactions with styrene, isoeugenol and 1-alkenes was discussed.
\end{abstract}

Keywords: 1,2-dihydro[1,3]thiazolo[3,2-a]quinolin-10-ium derivatives; annulation reactions; 2-quinolinesulfenyl chloride; 2-quinolinesulfenyl bromide; alkenes; cycloalkenes; 2-mercaptoquinoline

\section{Introduction}

The vast majority of drugs contain heterocyclic fragments in their structures [1]. The sulfur heterocycles are structural parts of many drugs that are used in modern pharmacotherapy [2]. Drugs containing condensed nitrogen and sulfur heterocycles are some of the most commonly used medications [2]. Penicillin and cephalosporin scaffolds contain condensed nitrogen and sulfur heterocycles and represent examples of antibiotics that played an outstanding role in the history and development of pharmaceutical chemistry.

The quinoline derivatives exhibit a variety of biological activities, including antibacterial, antifungal, anticancer, anti-inflammatory, antimalarial and antileishmanial actions [3-9]. The fluoroquinolone antibiotics (ciprofloxacin, levofloxacin, gatifloxacin and moxifloxacin) and antimalarial medications (chloroquine, hydroxychloroquine, amodiaquine and primaquine) took an important place in pharmacotherapy. It is worth noting that some quinoline derivatives (e.g., hydroxychloroquine) have been recently used for the treatment of COVID-19 [10].

The condensed system of quinoline and thiazole heterocycle is very promising in terms of possible manifestation of biological activity. The [1,3]thiazolo[3,2-a]quinolin10-ium scaffold derivatives represent an important class of condensed heterocyclic compounds exhibiting various types of biological activity including antibacterial [11-21], antitumor [22-24], anti-inflammatory [25] and antitrypanosomal [26] action as well as glycogen synthase kinase 3 inhibitors properties [24,27] (Figure 1). 
<smiles></smiles>

antibarterial activity<smiles>NC1CCN(c2cc3c(cc2F)c(=O)c(C(=O)O)c2n3CCS2)C1</smiles>

antibacterial activity<smiles>[R]OC(=O)c1c(=O)c2ccc(F)cc2n2c(-c3ccccc3)csc12</smiles>

antitumor activity<smiles>CCNC1CCN(c2c(F)cc3c(=O)c(C(=O)O)c4n(c3c2F)CCS4)C1</smiles>

antitrypanosomal activity<smiles>CC1CSc2c(C(=O)O)c(=O)c3c(N)c(F)c(NCCCc4ccccn4)c(F)c3n21</smiles>

GSK-3 inhibitory and antitumor activity<smiles>O=C(O)c1c(=O)c2cc(F)c(N3CCNCC3)cc2n2ccsc12</smiles>

antibacterial activity

Figure 1. Known biologically active compounds containing [1,3]thiazolo[3,2-a]quinolin-10-ium scaffold (antibacterial [11,16,21], antitumor [22,24], antitrypanosomal [26] and glycogen synthase kinase 3 inhibitor [24] activities).

The development of the effective synthesis of novel chalcogen condensed compounds and heterocycles by regioselective annulation and cyclization reactions of chalcogencontaining reagents is our favourable area of research [28-39]. The annulation reactions of 2-pyridinesulfenyl and 2-pyridineselenenyl halides with functionalized alkenes led to novel $2 \mathrm{H}, 3 \mathrm{H}$-[1,3]thiazolo[3,2-a]pyridin-4-ium and $2 \mathrm{H}, 3 \mathrm{H}$-[1,3]selenazolo[3,2-a]pyridin-4-ium derivatives in high yields [34-39].

Recently we described the annulation reactions of 8-quinolinesulfenyl halides with vinylic heteroatom compounds, including vinylic ethers, sulfides, divinyl selenide and tetravinyl silane [40]. Starting 8-quinolinesulfenyl halides were generated in situ from di(8-quinolinyl) disulfide by the action of sulfuryl chloride or bromine and used in further reactions without isolation (Scheme 1).<smiles>c1cnc2c(SSc3cccc4cccnc34)cccc2c1</smiles>

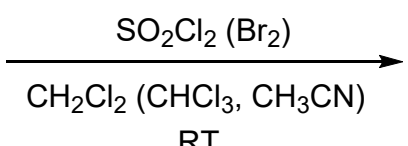

2<smiles>Sc1cccc2cccnc12</smiles><smiles>[R]C1CSc2cccc3ccc[n+]1c23</smiles>

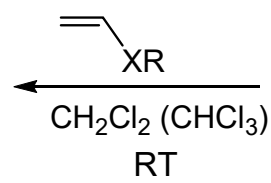<smiles>Sc1cccc2cccnc12</smiles><smiles>C=C[Si](C=C)(C=C)C=C</smiles><smiles></smiles>

$\mathrm{Hal}=\mathrm{Cl}, \mathrm{Br} ; \mathrm{XR}=\mathrm{OBu}-\mathrm{i}, \mathrm{OC}_{2} \mathrm{H}_{4} \mathrm{Cl} . \mathrm{SCH}=\mathrm{CH}_{2}, \mathrm{SPh}, \mathrm{SeCH}=\mathrm{CH}_{2}$

Scheme 1. The generation of 8-quinolinesulfenyl halides from di(8-quinolinyl) disulfide by the action of sulfuryl chloride or bromine followed by the annulation reactions with vinylic ethers, sulfides, divinyl selenide and tetravinyl silane. 
The annulation reactions of 8-quinolinesulfenyl halides with vinylic ethers, sulfides and divinyl selenide proceeded in a regioselective manner affording 3-substituted $2 \mathrm{H}, 3 \mathrm{H}$ $[1,4]$ thiazino[2,3,4-ij]quinolin-4-ium halides in high yields (Scheme 1) [40]. The annulation reaction of 8-quinolinesulfenyl halides with tetravinyl silane was found to occur with opposite regiochemistry leading to 2-trivinylsilyl-2 $\mathrm{H}, 3 \mathrm{H}$-[1,4]thiazino[2,3,4-ij]quinolin-4-ium halides in near quantitative yields (Scheme 1).

The reactions of 8-quinolinesulfenyl halides with cycloalkenes (cyclopentene, cyclohexene and cyclooctene), depending on the nature of the halogen, led to $[1,4]$ thiazino[2,3,4-ij]quinolin11-ium derivatives or 8-[(2-chlorocycloalkyl)sulfanyl]quinolines in high yields (90-100\%) (Scheme 2). The reactions of 8-quinolinesulfenyl chloride with cycloalkenes led to electrophilic addition products, while condensed compounds were obtained in the case of 8-quinolinesulfenyl bromide (Scheme 2) [41].<smiles>ClC1CCCC1Sc1cccc2cccnc12</smiles>

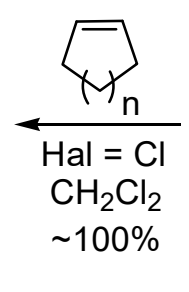<smiles>Sc1cccc2cccnc12</smiles>

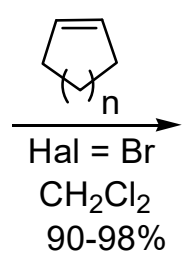<smiles>Br[N+]1=CC=Cc2cccc3c2[NH+]1CCCC3</smiles>

$\mathrm{Hal}=\mathrm{Cl}, \mathrm{Br} ; \mathrm{n}=1,2,4$

Scheme 2. The synthesis of [1,4]thiazino[2,3,4-ij]quinolin-11-ium derivatives and 8-[(2chlorocycloalkyl)sulfanyl]quinolines by the reactions of 8 -quinolinesulfenyl chloride and bromide with cycloalkenes.

The aim of this research is the development of the efficient regioselective synthesis of novel condensed [1,3]thiazolo[3,2-a] quinolin-10-ium derivatives with promising biological activity based on annulation reactions of 2-quinolinesulfenyl halides with alkenes and cycloalkenes. The annulation of 5-membered 1,3-thiazole heterocycle to the quinoline ring occurs in the reaction of 2-quinolinesulfenyl halides with alkenes and cycloalkenes, whereas the annulation of 6-membered 1,4-thiazine heterocycle to the quinoline ring is observed in the reactions of 8-quinolinesulfenyl halides with cycloalkenes and vinyl heteroatom compounds [40,41] (Schemes 1 and 2).

\section{Results and Discussion}

The reactions of 2-quinolinesulfenyl halides are unknown, and the preparation of 2-quinolinesulfenyl chloride and bromide has not yet been described in the literature (the SciFinder database). Previously we generated 8-quinolinesulfenyl halides from di(8quinolinyl) disulfide by the action of sulfuryl chloride or bromine and involved in further reactions without isolation (Scheme 1). However, di(2-quinolinyl) disulfide is a hard-to-get reagent, whereas 2-mercaptoquinoline is an available compound. It would seem that di(2-quinolinyl) disulfide can be easily prepared by oxidation of 2-mercaptoquinoline. Unfortunately, the oxidation reactions of 2-mercaptoquinoline are complicated by side processes that make it difficult to obtain pure di(2-quinolinyl) disulfide.

We developed a simple and efficient method for the generation of 2-quinolinesulfenyl chloride (2) and bromide (3) by the action of sulfuryl chloride or bromine on 2-mercaptoquinoline (1) in methylene chloride or chloroform. The generated 2-quinolinesulfenyl halides 2 and $\mathbf{3}$ were involved in further reactions without isolation (Scheme 3). 
<smiles>Sc1ccc2ccccc2n1</smiles>

1

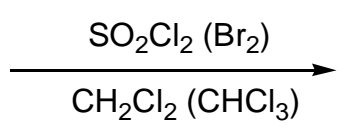

RT<smiles>Sc1ccc2ccccc2n1</smiles>

2,3

$\mathrm{Hal}=\mathrm{Cl}(2), \mathrm{Br}(3)$

Scheme 3. The simple and efficient method for generation of 2-quinolinesulfenyl chloride 2 and bromide 3 by the action of sulfuryl chloride or bromine on 2-mercaptoquinoline $\mathbf{1}$ in methylene chloride or chloroform.

The chemical properties of 2-quinolinesulfenyl chloride 2 and bromide $\mathbf{3}$ are unknown, and we started studies using simple terminal alkenes (1-hexene, 1-heptene and 1-octene) and cycloalkenes (cyclopentene, cyclohexene and cyclooctene).

We found that the reactions of 2-quinolinesulfenyl chloride 2 with 1-hexene, 1-heptene and 1-octene proceeded in a regioselective fashion at room temperature in methylene chloride or chloroform affording 2-alkyl-1,2-dihydro[1,3] thiazolo[3,2-a]quinolin-10-ium chlorides 4-6 in 95-100\% yields (Scheme 4). The electrophilic addition of the sulfur atom of 2 -quinolinesulfenyl chloride 2 occurred to the $\alpha$-carbon atom of the terminal double bond of alkenes in an anti-Markovnikov fashion.<smiles>Cl[SiH3]c1ccc2ccccc2n1</smiles>

2

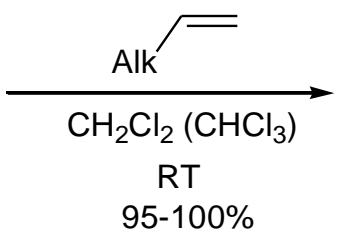

$95-100 \%$<smiles>Cl[n+]1cccc2ccccc21</smiles>

4-6

Alk = Bu (4), Pent (5), Hex (6)

Scheme 4. The synthesis of 2-alkyl-1,2-dihydro[1,3]thiazolo[3,2-a]quinolin-10-ium chlorides 4-6 by the reactions of sulfenyl chloride 2 with 1-hexene, 1-heptene and 1-octene.

Along with the investigation of the chemical properties of sulfenyl chloride 2 , the reactions of 2-quinolinesulfenyl bromide 3 with alkenes were studied. The reaction of sulfenyl bromide 3 with 1-heptene also proceeded regioselectively, leading to condensed compound 7 in a $99 \%$ yield (Scheme 5).<smiles>Brc1ccc2ccccc2n1</smiles>

3

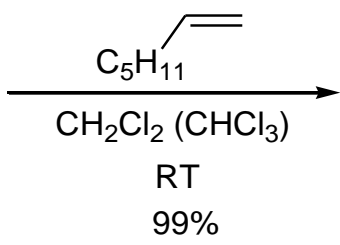

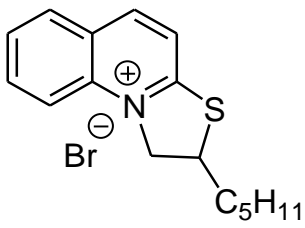

7

Scheme 5. The synthesis of 2-pentyl-1,2-dihydro[1,3]thiazolo[3,2-a]quinolin-10-ium bromide 7 by the reactions of sulfenyl bromide 3 with 1-heptene.

However, the reactions of 2-quinolinesulfenyl bromide 3 with alkenes containing an even number of carbon atoms (1-hexene and 1-octene) occurred with loss of regioselectivity giving along with compounds 8 and 9 (bromide analogues of products 4 and 6) minor regioisomers 10 and 11, which were originated from electrophilic addition of the sulfur atom of 2-quinolinesulfenyl bromide 3 to the terminal carbon atom of the double bond of alkenes (Scheme 6). A ratio of regioisomers, compounds 8/10 and 9/11, was found to be approximately 3:1. The total yields of regioisomers $\mathbf{8}+\mathbf{1 0}$ and $\mathbf{9}+\mathbf{1 1}$ are quantitative. 
<smiles>Brc1ccc2ccccc2n1</smiles><smiles>C=CC(C)CCCC</smiles>

RT<smiles></smiles>

8, 9<smiles></smiles>

10,11

$$
\text { Alk }=\operatorname{Bu}(\mathbf{8}, \mathbf{1 0}), \operatorname{Hex}(\mathbf{9}, \mathbf{1 1})
$$

$74-75 \%$

Scheme 6. The reactions of 2-quinolinesulfenyl bromide 3 with 1-hexene and 1-octene affording compounds 8-11.

The reactions of 2-quinolinesulfenyl chloride 2 and bromide 3 with cycloalkenes were also studied.

Previously we found that the reactions of 8-quinolinesulfenyl bromide with cycloalkenes led to condensed compounds, while in the case of 8-quinolinesulfenyl chloride electrophilic addition, products were obtained (Scheme 2). Unlike this trend, the reactions of cyclopentene with both sulfenyl chloride 2 and bromide 3 at room temperature in methylene chloride afforded condensed tetracyclic products $\mathbf{1 2}$ and $\mathbf{1 3}$ in $81 \%$ and quantitative yields, respectively (Scheme 7).<smiles>Sc1ccc2ccccc2n1</smiles>

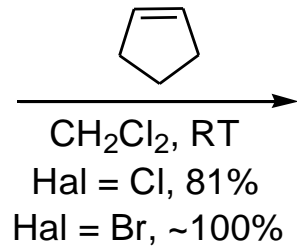

$\mathrm{Hal}=\mathrm{Cl}(12), \mathrm{Br}(13)$<smiles>c1ccc2c(c1)ccc1[n+]2[C@H]2CCCC2S1</smiles>

12,13

Scheme 7. The reactions of 2-quinolinesulfenyl chloride 2 and bromide 3 with cyclopentene leading to condensed tetracyclic compounds $\mathbf{1 2}$ and $\mathbf{1 3 .}$

The reactions of cyclohexene with both 2-quinolinesulfenyl chloride 2 and bromide 3 were accompanied by the formation of by-products, and it was difficult to separate the desired condensed compounds.

Unlike the reactions of cyclopentene with both 2-quinolinesulfenyl halides 2 and 3 giving condensed tetracyclic products 12 and 13, the reaction of 2-quinolinesulfenyl chloride $\mathbf{2}$ with cyclooctene at room temperature led to electrophilic addition product 14 in quantitative yield (Scheme 8). When sulfenyl bromide 3 was involved in the reaction with cyclooctene under similar conditions, tetracyclic condensed compound $\mathbf{1 5}$ was obtained in quantitative yield (Scheme 8).<smiles>ClC1CCCCCCC1Sc1ccc2ccccc2n1</smiles>

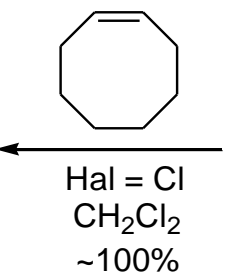

$\sim 100 \%$<smiles>Sc1ccc2ccccc2n1</smiles>

2,3

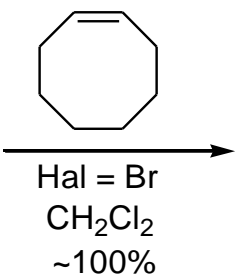

$\sim 100 \%$

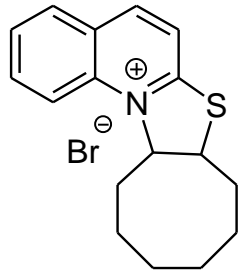

15

$\mathrm{Hal}=\mathrm{Cl}(2,14), \mathrm{Br}(3,15)$

Scheme 8. The reactions of 2-quinolinesulfenyl chloride 2 and bromide 3 with cyclooctene affording compounds 14 and 15. 


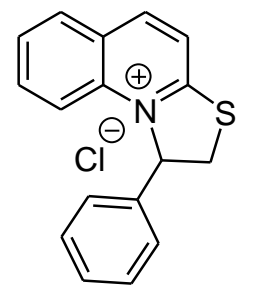

16

The formation of an intermediate bromine analogue of compound $\mathbf{1 4}$ is accompanied by intramolecular cyclization at room temperature with the formation of a condensed product 15, while chloro derivative $\mathbf{1 4}$ is less reactive under these conditions and remains uncyclized. It is known that the bromine atom is leaving group better than the chlorine atom in nucleophilic substitution reactions, and intramolecular cyclization with the bromine analogue of compound $\mathbf{1 4}$ proceeds easier than with chloro derivative $\mathbf{1 4}$.

Finally, we obtained condensed compounds from 2-quinolinesulfenyl chloride 2 and alkenes containing a benzene ring (Scheme 9). The reactions of 2-quinolinesulfenyl chloride 2 with styrene and natural product isoeugenol proceeded at room temperature in methylene chloride in a regioselective manner but with opposite regiochemistry compared to the reactions of sulfenyl chloride 2 with terminal alkenes (Scheme 4). The electrophilic addition of the sulfur atom of sulfenyl chloride 2 occurred to the $\beta$-carbon atom of the double bond of styrene and isoeugenol in a Markovnikov fashion. Condensed products 16 and 17 based on styrene and isoeugenol were obtained in quantitative and 80\% yields, respectively (Scheme 9).

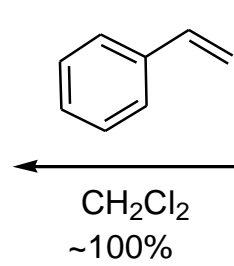

100\%<smiles>Cl[SiH]c1ccc2ccccc2n1</smiles>

2

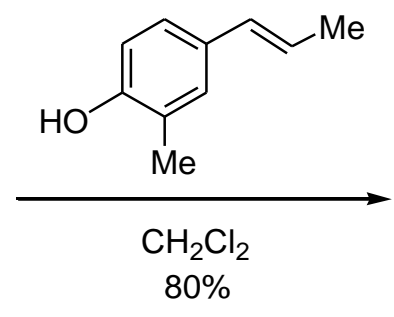

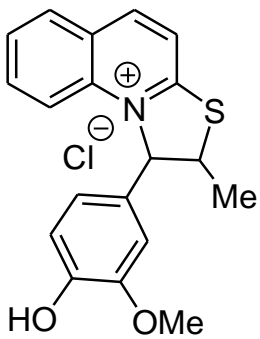

17

Scheme 9. The reactions of 2-quinolinesulfenyl chloride 2 with styrene and isoeugenol giving compounds 16 and 17.

Why do annulation reactions of quinolinesulfenyl chloride 2 with styrene, isoeugenol and terminal alkenes proceed with opposite regiochemistry? Supposed reaction pathways can be regarded in order to explain this trend (Scheme 10). The reactions of sulfenyl chloride 2 with compounds containing a double bond conjugated with the benzene ring (styrene, isoeugenol) proceeded regioselectively via electrophilic addition of the sulfur atom to the $\beta$-carbon atom of the double bond. The regioselectivity is due to the formation of intermediate linear carbocation $\mathbf{A}$, which is stabilized by the benzene ring (the relatively stable benzyl cation) (Scheme 10).
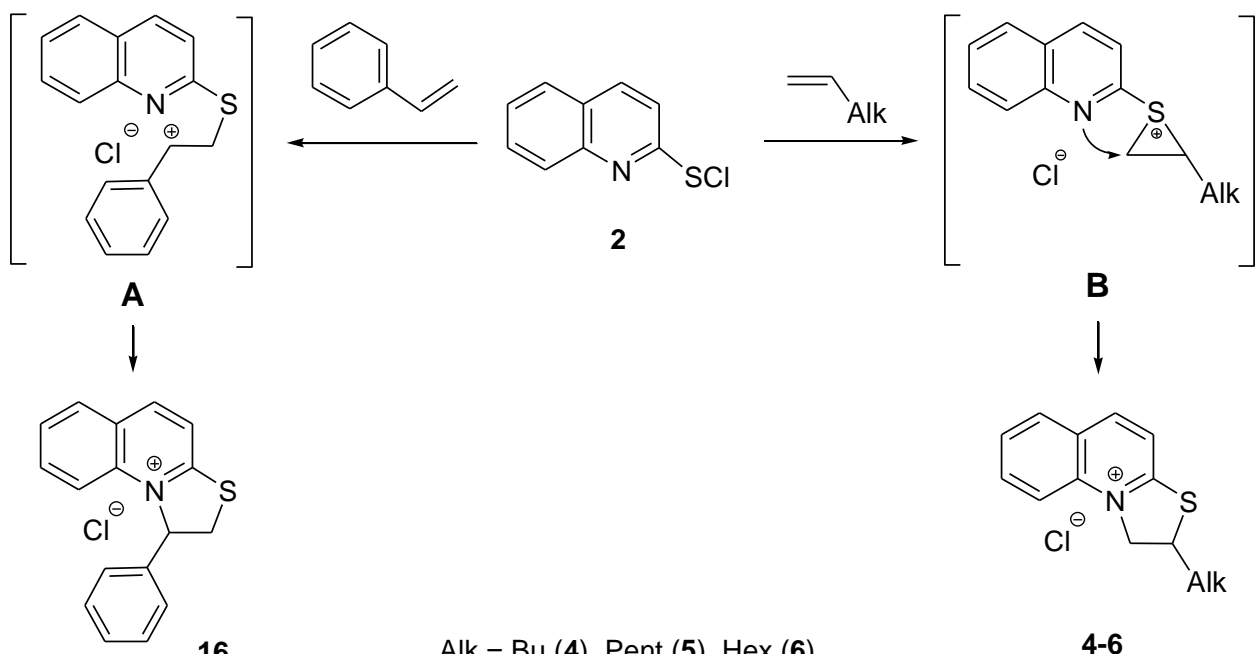

16

Alk = Bu (4), Pent (5), Hex (6)

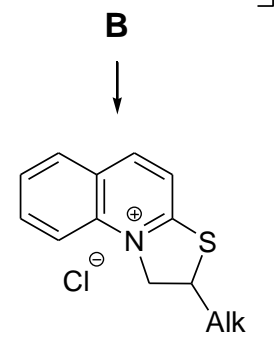

4-6

Scheme 10. The supposed pathways of the reactions of sulfenyl chloride 2 with styrene and 1-alkenes. 
Addition reactions of sulfenyl halides to alkenes are well understood [42-53], and it is known that the reactions of arylsulfenyl halides with styrene and its derivatives also afforded Markovnikov adducts [42,43].

It is worth noting that electrophilic addition of arylsulfenyl halides to linear 1-alkene afforded predominantly anti-Markovnikov products, and thiiranium cations were regarded as intermediates in these reactions [44-47]. Taking into account these data, we suppose that the reactions of quinolinesulfenyl chloride $\mathbf{2}$ with terminal alkenes proceeded via intermediates thiiranium cation $\mathbf{B}$ and nucleophilic attack of the nitrogen atom of the quinoline ring occurred at the least substituted carbon atom of thiiranium ion $\mathbf{B}$ leading to the formation of products 4-6 in an anti-Markovnikov fashion (Scheme 10).

The structural assignments of synthesized compounds were made using ${ }^{1} \mathrm{H}$ and ${ }^{13} \mathrm{C}$-NMR spectroscopy (see Supplementary Materials), including proton-coupled ${ }^{13} \mathrm{C}-\mathrm{NMR}$ spectra, and confirmed by elemental analysis.

The products of opposite regiochemistry exhibit characteristic signals of the carbon atoms bonded with charged nitrogen $\left(\mathrm{N}^{+}\right)$, sulfur atom and with one or two protons in ${ }^{13} \mathrm{C}$-NMR spectra of the obtained compounds (the number of protons is determined by NMR experiments). The CHS moiety and the $\mathrm{CH}_{2} \mathrm{~N}^{+}$methylene group manifest themselves in the regions of 44-48 ppm and 58-62 ppm, respectively, in ${ }^{13} \mathrm{C}-\mathrm{NMR}$ spectra of compounds 4-9 (the products derived from anti-Markovnikov addition of the sulfur electrophile to the double bond). Signals of the $\mathrm{CH}_{2} \mathrm{~S}$ group and containing one proton $\mathrm{CHN}^{+}$moiety are observed in the regions of 31-38 ppm and 66-71 ppm, respectively, in ${ }^{13} \mathrm{C}-\mathrm{NMR}$ spectra of compounds 10, 11 and 16 (the products derived from Markovnikov addition of the sulfur electrophile to the double bond).

Stereochemistry of compound $\mathbf{1 7}$ is determined based on the value of the spin-spin coupling constant $\left({ }^{3} \mathrm{~J}_{\mathrm{H}-\mathrm{H}}=8.2 \mathrm{~Hz}\right)$ of protons in the $\mathrm{N}-(\mathrm{Ar}) \mathrm{CH}-\mathrm{CH}(\mathrm{Me})-\mathrm{S}$ fragment. This value corresponds to the trans-disposition of methyl and aryl groups relative to the plane of the ring (trans-configuration) $[39,54,55]$.

\section{Experimental Section}

3.1. General Information

${ }^{1} \mathrm{H}(400.1 \mathrm{MHz})$ and ${ }^{13} \mathrm{C}(100.6 \mathrm{MHz}) \mathrm{NMR}$ spectra were recorded on a Bruker DPX-400 spectrometer (Bruker BioSpin $\mathrm{GmbH}$, Rheinstetten, Germany) in 2-5\% solution in $\mathrm{D}_{2} \mathrm{O}$. ${ }^{1} \mathrm{H}$ and ${ }^{13} \mathrm{C}$ chemical shifts $(\delta)$ are reported in parts per million (ppm), relative to tetramethylsilane (external) or to the residual solvent peaks of $\mathrm{D}_{2} \mathrm{O}(\delta=4.79)$, acetone- $d_{6}(\delta=2.05$ and $29.84 \mathrm{ppm})$ and DMSO- $d_{6}\left(\delta=2.50\right.$ and $39.52 \mathrm{ppm}$ for ${ }^{1} \mathrm{H}$ and ${ }^{13} \mathrm{C}$ NMR, respectively). Elemental analysis was performed on a Thermo Scientific FLASH 2000 Organic Elemental Analyzer (Thermo Fisher Scientific Inc., Milan, Italy). Melting points were determined on a Kofler Hot-Stage Microscope PolyTherm A apparatus (Wagner \& Munz GmbH, München, Germany). Absolute solvents were used in the reactions.

\subsection{Synthesis of Compounds $\mathbf{4 - 1 1}$ by the Reactions of 2-Quinolinesulfenyl Chloride $\mathbf{2}$ and Bromide $\mathbf{3}$ with Alkenes}

2-Butyl-1,2-dihydro[1,3]thiazolo[3,2-a]quinolin-10-ium chloride (4). A solution of sulfuryl chloride $(0.074 \mathrm{~g}, 0.55 \mathrm{mmol})$ in methylene chloride $(5 \mathrm{~mL})$ was added dropwise to a solution of 2-mercaptoquinoline $(0.089 \mathrm{~g}, 0.55 \mathrm{mmol})$ in methylene chloride $(5 \mathrm{~mL})$, and the mixture was stirred for $15 \mathrm{~min}$ at room temperature. The obtained solution of 2-quinolinesulfenyl chloride was added dropwise to a solution of 1-hexene $(0.093 \mathrm{~g}, 1.1 \mathrm{mmol})$ in methylene chloride $(5 \mathrm{~mL})$, and the reaction mixture was stirred for $20 \mathrm{~h}$ at room temperature. The solvent was removed by a rotary evaporator. The residue was washed with $\mathrm{CCl}_{4}$ and dried in vacuum, giving product $4(0.146 \mathrm{~g}, 95 \%$ yield $)$ as a yellow oil.

${ }^{1} \mathrm{H}-\mathrm{NMR}\left(400 \mathrm{MHz}, \mathrm{D}_{2} \mathrm{O}\right): \delta 0.81\left(\mathrm{t}, J 7.1 \mathrm{~Hz}, 3 \mathrm{H}, \mathrm{CH}_{3}\right), 1.25-1.40\left(\mathrm{~m}, 4 \mathrm{H}, \mathrm{CH}_{2}\right), 1.77-1.88$ (m, 1H, $\left.\mathrm{CH}_{2}\right), 1.89-1.99\left(\mathrm{~m}, 1 \mathrm{H}, \mathrm{CH}_{2}\right), 3.79$ (tt, J 8.7, $6.4 \mathrm{~Hz}, 1 \mathrm{H}, \mathrm{SCH}$ ), 5.00 (dd, J 13.0, 6.4 Hz, $\left.1 \mathrm{H}, \mathrm{NCH}_{2}\right), 5.25\left(\mathrm{dd}, J 13.0,8.7 \mathrm{~Hz}, 1 \mathrm{H}, \mathrm{NCH}_{2}\right), 7.66-7.72\left(\mathrm{~m}, 2 \mathrm{H}, \mathrm{C}_{\text {quino }}\right), 7.86-7.88(\mathrm{~m}, 1 \mathrm{H}$, $\left.\mathrm{C}_{\text {quino }}\right), 7.93-7.98\left(\mathrm{~m}, 1 \mathrm{H}, \mathrm{C}_{\text {quino }}\right), 8.00-8.02\left(\mathrm{~m}, 1 \mathrm{H}, \mathrm{C}_{\text {quino }}\right), 8.50-8.52\left(\mathrm{~m}, 1 \mathrm{H}, \mathrm{C}_{\text {quino }}\right)$. 
${ }^{13} \mathrm{C}-\mathrm{NMR}\left(101 \mathrm{MHz}, \mathrm{D}_{2} \mathrm{O}\right): \delta 11.82\left(\mathrm{CH}_{3}\right), 20.27,27.17,32.72\left(\mathrm{CH}_{2}\right), 45.44(\mathrm{SCH}), 59.82$ $\left(\mathrm{NCH}_{2}\right), 116.27\left(\mathrm{C}_{\text {quino }}\right), 116.84\left(\mathrm{C}_{\text {quino }}\right), 124.96\left(\mathrm{C}_{\text {quino }}\right), 127.06\left(\mathrm{C}_{\text {quino }}\right), 128.85\left(\mathrm{C}_{\text {quino }}\right)$, 133.87 ( $\left.\mathrm{C}_{\text {quino }}\right), 136.51$ ( $\left.\mathrm{C}_{\text {quino }}\right), 143.49\left(\mathrm{C}_{\text {quino }}\right), 163.60\left(\mathrm{C}_{\text {quino }}\right)$.

Anal. Calcd for $\mathrm{C}_{15} \mathrm{H}_{18} \mathrm{NClS}$ : C 64.38, H 6.48, Cl 12.67, N 5.01, S 11.46. Found: C 64.67, $\mathrm{H}$ 6.71, $\mathrm{Cl} 12.00$, N 5.29, S 11.89 .

2-Pentyl-1,2-dihydro[1,3]thiazolo[3,2-a]quinolin-10-ium chloride(5). A solution of sulfuryl chloride $(0.062 \mathrm{~g}, 0.46 \mathrm{mmol})$ in methylene chloride $(5 \mathrm{~mL})$ was added dropwise to a solution of 2-mercaptoquinoline $(0.074 \mathrm{~g}, 0.46 \mathrm{mmol})$ in methylene chloride $(5 \mathrm{~mL})$, and the mixture was stirred for $15 \mathrm{~min}$ at room temperature. The obtained solution of 2-quinolinesulfenyl chloride was added dropwise to a solution of 1-heptene $(0.09 \mathrm{~g}, 0.92 \mathrm{mmol})$ in methylene chloride $(5 \mathrm{~mL})$, and the reaction mixture was stirred for $20 \mathrm{~h}$ at room temperature. The solvent was removed by a rotary evaporator. The residue was washed with $\mathrm{CCl}_{4}$ and dried in vacuum, giving product $5(0.120 \mathrm{~g}, 100 \%$ yield $)$ as a yellow oil.

${ }^{1} \mathrm{H}-\mathrm{NMR}\left(400 \mathrm{MHz}, \mathrm{D}_{2} \mathrm{O}\right): \delta 0.79-0.82\left(\mathrm{~m}, 3 \mathrm{H}, \mathrm{CH}_{3}\right), 1.22-1.30\left(\mathrm{~m}, 4 \mathrm{H}, \mathrm{CH}_{2}\right), 1.37-1.46$ (m, 2H, $\left.\mathrm{CH}_{2}\right), 1.80-1.89\left(\mathrm{~m}, 1 \mathrm{H}, \mathrm{CH}_{2}\right), 1.90-1.97\left(\mathrm{~m}, 1 \mathrm{H}, \mathrm{CH}_{2}\right), 4.49$ (ddd, J 14.8, 8.7, 6.2 $\mathrm{Hz}, 1 \mathrm{H}, \mathrm{SCH}), 5.05\left(\mathrm{dd}, J\right.$ 13.0, $\left.6.2 \mathrm{~Hz}, 1 \mathrm{H}, \mathrm{NCH}_{2}\right), 5.30$ (dd, J 13.0, 8.7 Hz, 1H, $\mathrm{NCH}_{2}$ ), 7.72-7.77 (m, 2H, $\left.\mathrm{C}_{\text {quino }}\right), 7.91-7.93\left(\mathrm{~m}, 1 \mathrm{H}, \mathrm{C}_{\text {quino }}\right), 7.98-8.3\left(\mathrm{~m}, 1 \mathrm{H}, \mathrm{C}_{\text {quino }}\right), 8.06-8.08(\mathrm{~m}$, $\left.1 \mathrm{H}, \mathrm{C}_{\text {quino }}\right), 8.56-8.58\left(\mathrm{~m}, 1 \mathrm{H}, \mathrm{C}_{\text {quino }}\right)$.

${ }^{13} \mathrm{C}-\mathrm{NMR}\left(101 \mathrm{MHz}, \mathrm{D}_{2} \mathrm{O}\right): \delta 11.92\left(\mathrm{CH}_{3}\right), 20.44,24.66,29.18,32.99\left(\mathrm{CH}_{2}\right), 45.46$ $(\mathrm{SCH}), 59.82\left(\mathrm{NCH}_{2}\right), 116.27\left(\mathrm{C}_{\text {quino }}\right), 116.85\left(\mathrm{C}_{\text {quino }}\right), 125.03$ ( $\left.\mathrm{C}_{\text {quino }}\right), 127.07$ ( $\left.\mathrm{C}_{\text {quino }}\right)$, 128.89 ( $\left.\mathrm{C}_{\text {quino }}\right), 133.88\left(\mathrm{C}_{\text {quino }}\right), 136.59$ ( $\left.\mathrm{C}_{\text {quino }}\right), 143.54\left(\mathrm{C}_{\text {quino }}\right), 163.60$ ( $\left.\mathrm{C}_{\text {quino }}\right)$.

Anal. Calcd for $\mathrm{C}_{16} \mathrm{H}_{20} \mathrm{NClS}$ : C 65.40, $\mathrm{H}$ 6.86, Cl 12.06, N 4.77, S 10.91. Found: C 65.57, $\mathrm{H} 7.02, \mathrm{Cl} 12.57, \mathrm{~N}$ 4.93, S 11.42.

2-Hexyl-1,2-dihydro[1,3]thiazolo[3,2-a]quinolin-10-ium chloride (6). A solution of sulfuryl chloride $(0.052 \mathrm{~g}, 0.39 \mathrm{mmol})$ in methylene chloride $(5 \mathrm{~mL})$ was added dropwise to a solution of 2-mercaptoquinoline $(0.063 \mathrm{~g}, 0.39 \mathrm{mmol})$ in methylene chloride $(5 \mathrm{~mL})$, and the mixture was stirred for $15 \mathrm{~min}$ at room temperature. The obtained solution of 2-quinolinesulfenyl chloride was added dropwise to a solution of 1 -octene $(0.096 \mathrm{~g}, 0.78 \mathrm{mmol})$ in methylene chloride $(5 \mathrm{~mL})$, and the reaction mixture was stirred for $20 \mathrm{~h}$ at room temperature. The solvent was removed by a rotary evaporator. The residue was washed with $\mathrm{CCl}_{4}$ and dried in vacuum, giving product $6(0.097 \mathrm{~g}, 100 \%$ yield) as a light-yellow oil.

${ }^{1} \mathrm{H}-\mathrm{NMR}\left(400 \mathrm{MHz}, \mathrm{D}_{2} \mathrm{O}\right): \delta 0.79-0.82\left(\mathrm{~m}, 3 \mathrm{H}, \mathrm{CH}_{3}\right), 1.21-1.24\left(\mathrm{~m}, 4 \mathrm{H}, \mathrm{CH}_{2}\right), 1.29-1.32$ $\left(\mathrm{m}, 2 \mathrm{H}, \mathrm{CH}_{2}\right), 1.40-1.45\left(\mathrm{~m}, 2 \mathrm{H}, \mathrm{CH}_{2}\right), 1.82-1.89\left(\mathrm{~m}, 1 \mathrm{H}, \mathrm{CH}_{2}\right), 1.92-1.99\left(\mathrm{~m}, 1 \mathrm{H}, \mathrm{CH}_{2}\right)$, 4.49-4.53 (m, 1H, SCH), 5.00 (dd, J 13.0, $\left.6.3 \mathrm{~Hz}, 1 \mathrm{H}, \mathrm{NCH}_{2}\right), 5.25$ (dd, J 13.0, 8.7 Hz, 1H, $\left.\mathrm{NCH}_{2}\right), 7.74-7.79\left(\mathrm{~m}, 2 \mathrm{H}, \mathrm{C}_{\text {quino }}\right), 7.94-7.96\left(\mathrm{~m}, 1 \mathrm{H}, \mathrm{C}_{\text {quino }}\right), 8.00-8.03\left(\mathrm{~m}, 1 \mathrm{H}, \mathrm{C}_{\text {quino }}\right)$, 8.09-8.11 (m, 1H, $\left.\mathrm{C}_{\text {quino }}\right), 8.59-8.61\left(\mathrm{~m}, 1 \mathrm{H}, \mathrm{C}_{\text {quino }}\right)$.

${ }^{13} \mathrm{C}-\mathrm{NMR}\left(101 \mathrm{MHz}, \mathrm{D}_{2} \mathrm{O}\right): \delta 12.03\left(\mathrm{CH}_{3}\right), 20.55,24.90,26.60,29.49,33.03\left(\mathrm{CH}_{2}\right), 45.47$ $(\mathrm{SCH}), 59.86\left(\mathrm{NCH}_{2}\right), 116.31\left(\mathrm{C}_{\text {quino }}\right), 116.87\left(\mathrm{C}_{\text {quino }}\right), 124.98\left(\mathrm{C}_{\text {quino }}\right), 126.61\left(\mathrm{C}_{\text {quino }}\right), 128.94$ ( $\left.\mathrm{C}_{\text {quino }}\right), 133.79\left(\mathrm{C}_{\text {quino }}\right), 137.84\left(\mathrm{C}_{\text {quino }}\right), 143.59\left(\mathrm{C}_{\text {quino }}\right), 165.00\left(\mathrm{C}_{\text {quino }}\right)$.

Anal. Calcd for $\mathrm{C}_{17} \mathrm{H}_{22} \mathrm{NClS}$ : C 66.32, $\mathrm{H} 7.20, \mathrm{Cl} 11.52, \mathrm{~N} 4.55, \mathrm{~S} 10.42$. Found: C 66.58, H 7.39, Cl 11.88, N 4.72, S 10.90 .

2-Pentyl-1,2-dihydro[1,3]thiazolo[3,2-a]quinolin-10-ium bromide (7). A solution of bromide $(0.055 \mathrm{~g}, 0.34 \mathrm{mmol})$ in methylene chloride $(5 \mathrm{~mL})$ was added dropwise to a solution of 2-mercaptoquinoline $(0.055 \mathrm{~g}, 0.34 \mathrm{mmol})$ in methylene chloride $(5 \mathrm{~mL})$, and the mixture was stirred for $15 \mathrm{~min}$ at room temperature. The obtained solution of 2-quinolinesulfenyl bromide was added dropwise to a solution of 1 -heptene $(0.067 \mathrm{~g}, 0.68 \mathrm{mmol})$ in methylene chloride $(5 \mathrm{~mL})$, and the reaction mixture was stirred for $20 \mathrm{~h}$ at room temperature. The solvent was removed by a rotary evaporator. The residue was washed with $\mathrm{CCl}_{4}$ and dried in vacuum, giving product $7(0.114 \mathrm{~g}, 99 \%$ yield $)$ as an orange oil.

${ }^{1} \mathrm{H}-\mathrm{NMR}\left(400 \mathrm{MHz}, \mathrm{D}_{2} \mathrm{O}\right): \delta 0.73\left(\mathrm{t}, \mathrm{J} 6.8 \mathrm{~Hz}, 3 \mathrm{H}, \mathrm{CH}_{3}\right), 1.15-1.24\left(\mathrm{~m}, 4 \mathrm{H}, \mathrm{CH}_{2}\right), 1.30$ $1.42\left(\mathrm{~m}, 2 \mathrm{H}, \mathrm{CH}_{2}\right), 1.77-1.92\left(\mathrm{~m}, 2 \mathrm{H}, \mathrm{CH}_{2}\right), 4.40-4.47(\mathrm{~m}, 1 \mathrm{H}, \mathrm{SCH}), 5.02(\mathrm{dd}, J 12.9,6.3 \mathrm{~Hz}$, $\left.1 \mathrm{H}, \mathrm{NCH}_{2}\right), 7.34\left(\mathrm{~d}, J 12.9,8.8 \mathrm{~Hz}, 1 \mathrm{H}, \mathrm{NCH}_{2}\right), 7.65-7.71\left(\mathrm{~m}, 2 \mathrm{H}, \mathrm{C}_{\text {quino }}\right), 7.86-7.89(\mathrm{~m}, 1 \mathrm{H}$, $\left.\mathrm{C}_{\text {quino }}\right), 7.92-7.96\left(\mathrm{~m}, 1 \mathrm{H}, \mathrm{C}_{\text {quino }}\right), 8.01-8.03\left(\mathrm{~m}, 1 \mathrm{H}, \mathrm{C}_{\text {quino }}\right), 8.51-8.53\left(\mathrm{~m}, 1 \mathrm{H}, \mathrm{C}_{\text {quino }}\right)$. 
${ }^{13} \mathrm{C}-\mathrm{NMR}\left(101 \mathrm{MHz}, \mathrm{D}_{2} \mathrm{O}\right): \delta 14.14\left(\mathrm{CH}_{3}\right), 22.65,26.89,31.38,35.20\left(\mathrm{CH}_{2}\right), 47.67$ $(\mathrm{SCH}), 62.09\left(\mathrm{NCH}_{2}\right), 118.56\left(\mathrm{C}_{\text {quino }}\right), 119.56\left(\mathrm{C}_{\text {quino }}\right), 127.30\left(\mathrm{C}_{\text {quino }}\right), 129.20\left(\mathrm{C}_{\text {quino }}\right), 131.09$ ( $\left.\mathrm{C}_{\text {quino }}\right), 136.00$ ( $\left.\mathrm{C}_{\text {quino }}\right), 145.72\left(\mathrm{C}_{\text {quino }}\right)$.

Anal. Calcd for $\mathrm{C}_{16} \mathrm{H}_{20} \mathrm{NBrS}$ : C 56.80, H 5.96, Br 23.62, N 4.14, S 9.48. Found: C 57.02, H 6.21, Br 23.98, N 4.40, S 9.91.

2-Butyl-1,2-dihydro[1,3]thiazolo[3,2- $\alpha$ ]quinolin-10-ium bromide (8) and 1-butyl-1,2-dihydro[1,3] thiazolo[3,2- $\alpha$ ]quinolin-10-ium bromide (10). A solution of bromide $(0.048 \mathrm{~g}, 0.30 \mathrm{mmol})$ in methylene chloride $(5 \mathrm{~mL})$ was added dropwise to a solution of 2-mercaptoquinoline $(0.048 \mathrm{~g}, 0.30 \mathrm{mmol})$ in methylene chloride $(5 \mathrm{~mL})$, and the mixture was stirred for $15 \mathrm{~min}$ at room temperature. The obtained solution of 2-quinolinesulfenyl bromide was added dropwise to a solution of 1-hexene $(0.050 \mathrm{~g}, 0.60 \mathrm{mmol})$ in methylene chloride $(5 \mathrm{~mL})$, and the reaction mixture was stirred for $20 \mathrm{~h}$ at room temperature. The solvent was removed by a rotary evaporator. The residue was washed with $\mathrm{CCl}_{4}$ and dried in vacuum, giving a mixture ( $0.097 \mathrm{~g})$ of products 8 (0.073 g, 75\% yield) and 10 (0.024 g, 24\% yield) as a yellow oil.

2-Butyl-1,2-dihydro[1,3] thiazolo[3,2-a]quinolin-10-ium bromide (8). ${ }^{1} \mathrm{H}-\mathrm{NMR}\left(400 \mathrm{MHz}, \mathrm{D}_{2} \mathrm{O}\right)$ :

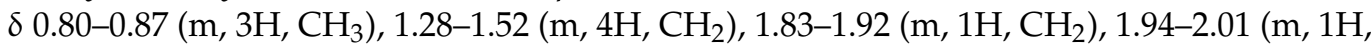
$\mathrm{CH}_{2}$ ), 4.52 (dd, J 8.3, $\left.6.4 \mathrm{~Hz}, 1 \mathrm{H}, \mathrm{SCH}\right), 5.05$ (dd, J 13.0, $\left.6.4 \mathrm{~Hz}, 1 \mathrm{H}, \mathrm{NCH}_{2}\right), 5.30$ (dd, J 13.0, $\left.8.3 \mathrm{~Hz}, 1 \mathrm{H}, \mathrm{NCH}_{2}\right), 7.71-7.79\left(\mathrm{~m}, 2 \mathrm{H}, \mathrm{C}_{\text {quino }}\right), 7.91-7.93\left(\mathrm{~m}, 1 \mathrm{H}, \mathrm{C}_{\text {quino }}\right), 7.97-8.02(\mathrm{~m}, 1 \mathrm{H}$, $\left.\mathrm{C}_{\text {quino }}\right), 8.05-8.07\left(\mathrm{~m}, 1 \mathrm{H}, \mathrm{C}_{\text {quino }}\right), 8.54-8.56\left(\mathrm{~m}, 1 \mathrm{H}, \mathrm{C}_{\text {quino }}\right)$.

${ }^{13} \mathrm{C}-\mathrm{NMR}\left(101 \mathrm{MHz}, \mathrm{D}_{2} \mathrm{O}\right)$ (multiplicities are given based on the proton-coupled ${ }^{13} \mathrm{C}-\mathrm{NMR}$ spectrum): $\delta 10.36\left(\mathrm{q}, \mathrm{CH}_{3}\right), 18.80,25.69,31.25\left(\mathrm{t}, \mathrm{CH}_{2}\right), 43.97(\mathrm{~d}, \mathrm{SCH}), 58.35(\mathrm{t}$, $\left.\mathrm{NCH}_{2}\right), 114.80\left(\mathrm{~d}, \mathrm{C}_{\text {quino }}\right), 115.37\left(\mathrm{~d}, \mathrm{C}_{\text {quino }}\right), 123.40\left(\mathrm{~d}, \mathrm{C}_{\text {quino }}\right), 125.58$ (s, $\left.\mathrm{C}_{\text {quino }}\right), 127.34(\mathrm{~d}$, $\left.\mathrm{C}_{\text {quino }}\right), 132.40\left(\mathrm{~d}, \mathrm{C}_{\text {quino }}\right), 134.97$ (s, $\left.\mathrm{C}_{\text {quino }}\right), 141.99\left(\mathrm{~d}, \mathrm{C}_{\text {quino }}\right), 162.08$ (s, $\left.\mathrm{C}_{\text {quino }}\right)$.

1-Butyl-1,2-dihydro[1,3] thiazolo[3,2-a]quinolin-10-ium bromide (10). ${ }^{1} \mathrm{H}-\mathrm{NMR}\left(400 \mathrm{MHz}, \mathrm{D}_{2} \mathrm{O}\right)$ :

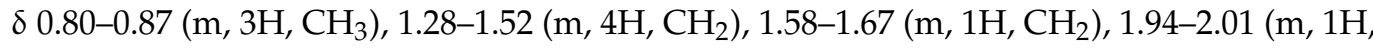
$\left.\mathrm{CH}_{2}\right), 3.79\left(\mathrm{~d}, J 12.1 \mathrm{~Hz}, 1 \mathrm{H}, \mathrm{SCH}_{2}\right), 5.02\left(\mathrm{dd}, J 12.1,8.3 \mathrm{~Hz}, 1 \mathrm{H}, \mathrm{SCH}_{2}\right), 5.96(\mathrm{t}, J 9.4 \mathrm{~Hz}$, $1 \mathrm{H}, \mathrm{NCH}), 7.71-7.79\left(\mathrm{~m}, 2 \mathrm{H}, \mathrm{C}_{\text {quino }}\right), 8.00-8.04\left(\mathrm{~m}, 2 \mathrm{H}, \mathrm{C}_{\text {quino }}\right), 8.05-8.07\left(\mathrm{~m}, 1 \mathrm{H}, \mathrm{C}_{\text {quino }}\right)$, 8.54-8.56 (m, 1H, $\left.\mathrm{C}_{\text {quino }}\right)$.

${ }^{13} \mathrm{C}-\mathrm{NMR}\left(101 \mathrm{MHz}, \mathrm{D}_{2} \mathrm{O}\right)$ (multiplicities are given based on the proton-coupled ${ }^{13} \mathrm{C}-\mathrm{NMR}$ spectrum): $\delta 10.36\left(\mathrm{q}, \mathrm{CH}_{3}\right), 18.95,24.13,26.85\left(\mathrm{t}, \mathrm{CH}_{2}\right), 30.99\left(\mathrm{t}, \mathrm{SCH}_{2}\right), 66.61(\mathrm{~d}$, $\mathrm{NCH}), 115.10$ (d, $\left.\mathrm{C}_{\text {quino }}\right), 115.55$ (d, $\left.\mathrm{C}_{\text {quino }}\right), 123.42\left(\mathrm{~d}, \mathrm{C}_{\text {quino }}\right), 125.60$ (s, $\left.\mathrm{C}_{\text {quino }}\right), 127.67$ (d, $\mathrm{C}_{\text {quino }}$ ), 132.39 (d, $\left.\mathrm{C}_{\text {quino }}\right), 134.98$ (s, $\left.\mathrm{C}_{\text {quino }}\right), 141.97\left(\mathrm{~d}, \mathrm{C}_{\text {quino }}\right), 161.66$ (s, $\left.\mathrm{C}_{\text {quino }}\right)$.

Anal. Calcd for $\mathrm{C}_{15} \mathrm{H}_{18} \mathrm{NBrS}$ : C 55.56, H 5.59, Br 24.64, N 4.32, S 9.89. Found: C 55.89, H 5.78, Br 24.91, N 4.60, S 10.25.

2-Hexyl-1,2-dihydro[1,3]thiazolo[3,2-a]quinolin-10-ium bromide (9) and 1-hexyl-1,2-dihydro[1,3] thiazolo[3,2-a]quinolin-10-ium bromide (11). A solution of bromide $(0.063 \mathrm{~g}, 0.39 \mathrm{mmol})$ in methylene chloride $(5 \mathrm{~mL})$ was added dropwise to a solution of 2-mercaptoquinoline $(0.063 \mathrm{~g}, 0.39 \mathrm{mmol})$ in methylene chloride $(5 \mathrm{~mL})$, and the mixture was stirred for $15 \mathrm{~min}$ at room temperature. The obtained solution of 2-quinolinesulfenyl bromide was added dropwise to a solution of 1-octene $(0.096 \mathrm{~g}, 0.78 \mathrm{mmol})$ in methylene chloride $(5 \mathrm{~mL})$, and the reaction mixture was stirred for $20 \mathrm{~h}$ at room temperature. The solvent was removed by a rotary evaporator. The residue was washed with $\mathrm{CCl}_{4}$ and dried in vacuum, giving a mixture (0.12 g) of products 9 ( $0.089 \mathrm{~g}, 74 \%$ yield) and $11(0.031 \mathrm{~g}, 26 \%$ yield $)$ as a yellow oil.

2-Hexyl-1,2-dihydro[1,3] thiazolo[3,2-a]quinolin-10-ium bromide (9). ${ }^{1} \mathrm{H}-\mathrm{NMR}(400 \mathrm{MHz}, \mathrm{DMSO}-$ $\left.d_{6}\right): \delta 0.80-0.84\left(\mathrm{~m}, 3 \mathrm{H}, \mathrm{CH}_{3}\right), 1.26-1.32\left(\mathrm{~m}, 6 \mathrm{H}, \mathrm{CH}_{2}\right), 1.36-1.51\left(\mathrm{~m}, 2 \mathrm{H}, \mathrm{CH}_{2}\right), 1.84-1.99$ $\left(\mathrm{m}, 2 \mathrm{H}, \mathrm{CH}_{2}\right), 4.59-4.63(\mathrm{~m}, 1 \mathrm{H}, \mathrm{SCH}), 5.30-5.34\left(\mathrm{~m}, 1 \mathrm{H}, \mathrm{NCH}_{2}\right), 5.45-5.49\left(\mathrm{~m}, 1 \mathrm{H}, \mathrm{NCH}_{2}\right)$, 7.85-7.89 (m, 1H, $\left.\mathrm{C}_{\text {quino }}\right), 8.12-8.15\left(\mathrm{~m}, 1 \mathrm{H}, \mathrm{C}_{\text {quino }}\right), 8.20-8.25\left(\mathrm{~m}, 1 \mathrm{H}, \mathrm{C}_{\text {quino }}\right), 8.28-8.30(\mathrm{~m}$, $\left.1 \mathrm{H}, \mathrm{C}_{\text {quino }}\right), 8.32-8.37\left(\mathrm{~m}, 1 \mathrm{H}, \mathrm{C}_{\text {quino }}\right), 8.96-8.98\left(\mathrm{~m}, 1 \mathrm{H}, \mathrm{C}_{\text {quino }}\right)$.

${ }^{13} \mathrm{C}-\mathrm{NMR}\left(101 \mathrm{MHz}, \mathrm{DMSO}-d_{6}\right): \delta 13.93\left(\mathrm{CH}_{3}\right), 21.99,26.40,28.23,31.02,34.21\left(\mathrm{CH}_{2}\right)$, $46.57(\mathrm{SCH}), 61.17\left(\mathrm{NCH}_{2}\right), 118.80\left(\mathrm{C}_{\text {quino }}\right), 119.03\left(\mathrm{C}_{\text {quino }}\right), 126.28\left(\mathrm{C}_{\text {quino }}\right), 128.16\left(\mathrm{C}_{\text {quino }}\right)$, $130.06\left(\mathrm{C}_{\text {quino }}\right), 134.78\left(\mathrm{C}_{\text {quino }}\right), 137.90\left(\mathrm{C}_{\text {quino }}\right), 144.62\left(\mathrm{C}_{\text {quino }}\right), 164.46\left(\mathrm{C}_{\text {quino }}\right)$. 
1-Hexyl-1,2-dihydro[1,3]thiazolo[3,2-a]quinolin-10-ium bromide (11). ${ }^{1} \mathrm{H}-\mathrm{NMR}(400 \mathrm{MHz}$, DMSO- $\left.d_{6}\right): \delta 0.80-0.84\left(\mathrm{~m}, 3 \mathrm{H}, \mathrm{CH}_{3}\right), 1.26-1.32\left(\mathrm{~m}, 4 \mathrm{H}, \mathrm{CH}_{2}\right), 1.36-1.51\left(\mathrm{~m}, 2 \mathrm{H}, \mathrm{CH}_{2}\right)$, 1.59-1.76 (m, 2H, $\left.\mathrm{CH}_{2}\right), 3.84-3.97\left(\mathrm{~m}, 2 \mathrm{H}, \mathrm{CH}_{2}\right), 4.18-4.22\left(\mathrm{~m}, 1 \mathrm{H}, \mathrm{SCH}_{2}\right), 4.36-4.42(\mathrm{~m}$, $\left.1 \mathrm{H}, \mathrm{SCH}_{2}\right), 6.21-6.25(\mathrm{~m}, 1 \mathrm{H}, \mathrm{NCH}), 8.12-8.15\left(\mathrm{~m}, 1 \mathrm{H}, \mathrm{C}_{\text {quino }}\right), 8.20-8.25\left(\mathrm{~m}, 1 \mathrm{H}, \mathrm{C}_{\text {quino }}\right)$, 8.28-8.32 (m, $\left.2 \mathrm{H}, \mathrm{C}_{\text {quino }}\right), 8.32-8.37\left(\mathrm{~m}, 1 \mathrm{H}, \mathrm{C}_{\text {quino }}\right), 8.96-8.99\left(\mathrm{~m}, 1 \mathrm{H}, \mathrm{C}_{\text {quino }}\right)$.

${ }^{13} \mathrm{C}-\mathrm{NMR}\left(101 \mathrm{MHz}, \mathrm{DMSO}-d_{6}\right): \delta 24.70\left(\mathrm{CH}_{3}\right), 26.35,27.88,28.38,29.96,31.02\left(\mathrm{CH}_{2}\right)$, $35.96\left(\mathrm{SCH}_{2}\right), 68.74(\mathrm{NCH}), 118.70\left(\mathrm{C}_{\text {quino }}\right), 119.05\left(\mathrm{C}_{\text {quino }}\right), 126.30\left(\mathrm{C}_{\text {quino }}\right), 126.73\left(\mathrm{C}_{\text {quino }}\right)$, 130.52 ( $\left.\mathrm{C}_{\text {quino }}\right), 135.06\left(\mathrm{C}_{\text {quino }}\right), 136.76\left(\mathrm{C}_{\text {quino }}\right), 144.84\left(\mathrm{C}_{\text {quino }}\right), 164.30\left(\mathrm{C}_{\text {quino }}\right)$.

Anal. Calcd for $\mathrm{C}_{17} \mathrm{H}_{22} \mathrm{NBrS}$ : C 57.95, H 6.29, Br 22.68, N 3.98, S 9.10. Found: C 58.16, H 6.46, Br 23.01, N 4.24, S 9.49.

\subsection{Synthesis of Compounds 12-15 by the Reactions of Quinolinesulfenyl Chloride $\mathbf{2}$ and Bromide 3 with Cycloalkenes}

8,9,10,10a-Tetrahydro-7aH-cyclopenta[4,5][1,3]thiazolo[3,2-a]quinolin-11-ium chloride (12). A solution of sulfuryl chloride $(0.074 \mathrm{~g}, 0.55 \mathrm{mmol})$ in methylene chloride $(5 \mathrm{~mL})$ was added dropwise to a solution of 2-mercaptoquinoline $(0.088 \mathrm{~g}, 0.55 \mathrm{mmol})$ in methylene chloride $(5 \mathrm{~mL})$, and the mixture was stirred for $15 \mathrm{~min}$ at room temperature. The obtained solution of 2-quinolinesulfenyl chloride was added dropwise to a solution of cyclopentene $(0.075 \mathrm{~g}$, $1.1 \mathrm{mmol})$ in methylene chloride $(5 \mathrm{~mL})$, and the reaction mixture was stirred for $94 \mathrm{~h}$ at room temperature. The solvent was removed by a rotary evaporator. The residue was washed with $\mathrm{CCl}_{4}$ and dried in vacuum, giving the product $12(0.153 \mathrm{~g}, 81 \%$ yield) as a brown oil.

${ }^{1} \mathrm{H}-\mathrm{NMR}\left(400 \mathrm{MHz}, \mathrm{D}_{2} \mathrm{O}\right): 81.83-1.90\left(\mathrm{~m}, 2 \mathrm{H}, \mathrm{CH}_{2}\right), 2.06-2.17\left(\mathrm{~m}, 2 \mathrm{H}, \mathrm{CH}_{2}\right), 2.23-2.31$ $\left(\mathrm{m}, 1 \mathrm{H}, \mathrm{CH}_{2}\right), 2.47-2.57\left(\mathrm{~m}, 1 \mathrm{H}, \mathrm{CH}_{2}\right), 4.91-4.95(\mathrm{~m}, 1 \mathrm{H}, \mathrm{SCH}), 6.03-6.07(\mathrm{~m}, 1 \mathrm{H}, \mathrm{NCH})$, 7.62-7.65 (m, 1H, $\left.\mathrm{C}_{\text {quino }}\right), 7.69-7.73\left(\mathrm{~m}, 1 \mathrm{H}, \mathrm{C}_{\text {quino }}\right), 7.88-7.90\left(\mathrm{~m}, 1 \mathrm{H}, \mathrm{C}_{\text {quino }}\right), 7.94-7.99(\mathrm{~m}$, $\left.1 \mathrm{H}, \mathrm{C}_{\text {quino }}\right), 8.02-8.04\left(\mathrm{~m}, 1 \mathrm{H}, \mathrm{C}_{\text {quino }}\right), 8.47-8.50\left(\mathrm{~m}, 1 \mathrm{H}, \mathrm{C}_{\text {quino }}\right)$.

${ }^{13} \mathrm{C}-\mathrm{NMR}\left(101 \mathrm{MHz}, \mathrm{D}_{2} \mathrm{O}\right): \delta 23.77,34.60,34.76\left(\mathrm{CH}_{2}\right), 49.78(\mathrm{SCH}), 75.12(\mathrm{NCH})$, $117.67\left(\mathrm{C}_{\text {quino }}\right), 118.06\left(\mathrm{C}_{\text {quino }}\right), 126.76\left(\mathrm{C}_{\text {quino }}\right), 128.28\left(\mathrm{C}_{\text {quino }}\right), 130.42\left(\mathrm{C}_{\text {quino }}\right), 134.90$ $\left(\mathrm{C}_{\text {quino }}\right), 137.50$ ( $\left.\mathrm{C}_{\text {quino }}\right), 144.69\left(\mathrm{C}_{\text {quino }}\right), 165.39\left(\mathrm{C}_{\text {quino }}\right)$.

Anal. Calcd for $\mathrm{C}_{14} \mathrm{H}_{14} \mathrm{NClS}$ : C 63.74, $\mathrm{H}$ 5.35, $\mathrm{Cl} 13.44, \mathrm{~N} 5.31, \mathrm{~S}$ 12.16. Found: C 63.91, H 5.59, Cl 13.79, N 5.52, S 12.52 .

8,9,10,10a-Tetrahydro-7aH-cyclopenta[4,5][1,3]thiazolo[3,2-a]quinoli-11-ium bromide (13). A solution of bromide $(0.060 \mathrm{~g}, 0.38 \mathrm{mmol})$ in methylene chloride $(5 \mathrm{~mL})$ was added dropwise to a solution of 2-mercaptoquinoline $(0.061 \mathrm{~g}, 0.38 \mathrm{mmol})$ in methylene chloride $(5 \mathrm{~mL})$, and the mixture was stirred for $15 \mathrm{~min}$ at room temperature. The obtained solution of 2-quinolinesulfenyl chloride was added dropwise to a solution of cyclopentene $(0.052 \mathrm{~g}$, $0.76 \mathrm{mmol}$ ) in methylene chloride $(5 \mathrm{~mL})$, and the reaction mixture was stirred for $20 \mathrm{~h}$ at room temperature. The solvent was removed by a rotary evaporator. The residue was washed with $\mathrm{CCl}_{4}$ and dried in vacuum, giving product $13(0.117 \mathrm{~g}, 100 \%$ yield $)$ as a light-yellow oil.

${ }^{1} \mathrm{H}-\mathrm{NMR}\left(400 \mathrm{MHz}, \mathrm{D}_{2} \mathrm{O}\right): 81.76-1.82\left(\mathrm{~m}, 2 \mathrm{H}, \mathrm{CH}_{2}\right), 1.90-1.95\left(\mathrm{~m}, 1 \mathrm{H}, \mathrm{CH}_{2}\right), 2.07-2.12$ $\left(\mathrm{m}, 1 \mathrm{H}, \mathrm{CH}_{2}\right), 2.19-2.27\left(\mathrm{~m}, 1 \mathrm{H}, \mathrm{CH}_{2}\right), 2.41-2.51\left(\mathrm{~m}, 1 \mathrm{H}, \mathrm{CH}_{2}\right), 4.85-4.89(\mathrm{~m}, 1 \mathrm{H}, \mathrm{SCH})$, 5.92-5.96 (m, 1H, NCH), 7.55-7.64 (m, 2H, $\left.\mathrm{C}_{\text {quino }}\right), 7.78-7.80\left(\mathrm{~m}, 1 \mathrm{H}, \mathrm{C}_{\text {quino }}\right), 7.86-7.94(\mathrm{~m}$, $\left.2 \mathrm{H}, \mathrm{C}_{\text {quino }}\right), 8.38-8.40\left(\mathrm{~m}, 1 \mathrm{H}, \mathrm{C}_{\text {quino }}\right)$.

${ }^{13} \mathrm{C}-\mathrm{NMR}\left(101 \mathrm{MHz}, \mathrm{D}_{2} \mathrm{O}\right): \delta 23.79,34.67,34.81\left(\mathrm{CH}_{2}\right), 49.82(\mathrm{SCH}), 75.02(\mathrm{NCH})$, $117.72\left(\mathrm{C}_{\text {quino }}\right), 118.03\left(\mathrm{C}_{\text {quino }}\right), 126.50\left(\mathrm{C}_{\text {quino }}\right), 128.29\left(\mathrm{C}_{\text {quino }}\right), 130.32\left(\mathrm{C}_{\text {quino }}\right), 134.94$ $\left(\mathrm{C}_{\text {quino }}\right), 137.02$ ( $\left.\mathrm{C}_{\text {quino }}\right), 144.54\left(\mathrm{C}_{\text {quino }}\right), 165.33\left(\mathrm{C}_{\text {quino }}\right)$.

Anal. Calcd for $\mathrm{C}_{14} \mathrm{H}_{14} \mathrm{NBrS}$ : C 54.55, H 4.58, Br 28.92, N 4.54, S 10.40. Found: C 54.69, $\mathrm{H} 4.82, \mathrm{Br} 26.34, \mathrm{~N} 4.71, \mathrm{~S} 10.86$.

2-(2-Chlorocyclooctylsulfanyl)quinoline (14). A solution of sulfuryl chloride $(0.059 \mathrm{~g}, 0.44 \mathrm{mmol})$ in methylene chloride $(5 \mathrm{~mL})$ was added dropwise to a solution of 2-mercaptoquinoline $(0.070 \mathrm{~g}, 0.44 \mathrm{mmol})$ in methylene chloride $(5 \mathrm{~mL})$, and the mixture was stirred for $15 \mathrm{~min}$ at room temperature. A solution of vinyl isobutyl ether $(0.098 \mathrm{~g}$, 
$0.98 \mathrm{mmol})$ in methylene chloride $(5 \mathrm{~mL})$ was added dropwise, and the reaction mixture was stirred for $100 \mathrm{~h}$ at room temperature. The solvent was removed by a rotary evaporator. The residue was washed with $\mathrm{CCl}_{4}$ and dried in vacuum, giving product $14(0.119 \mathrm{~g}$, $100 \%$ yield) as a light-yellow oil.

${ }^{1} \mathrm{H}-\mathrm{NMR}\left(400 \mathrm{MHz}\right.$, acetone- $\left.d_{6}\right): \delta 1.53-1.72\left(\mathrm{~m}, 4 \mathrm{H}, \mathrm{CH}_{2}\right), 1.76-1.87\left(\mathrm{~m}, 3 \mathrm{H}, \mathrm{CH}_{2}\right)$, 1.93-1.99 (m, 1H, CH $), 2.08-2.16\left(\mathrm{~m}, 2 \mathrm{H}, \mathrm{CH}_{2}\right), 2.28-2.41\left(\mathrm{~m}, 2 \mathrm{H}, \mathrm{CH}_{2}\right), 4.51-4.54(\mathrm{~m}, 1 \mathrm{H}$, $\mathrm{SCH}), 4.73-4.78(\mathrm{~m}, 1 \mathrm{H}, \mathrm{CHCl}), 7.44-7.45$ (m, 1H, $\left.\mathrm{C}_{\text {quino }}\right), 7.55-7.57$ (m, 1H, $\left.\mathrm{C}_{\text {quino }}\right), 7.75-7.79$ (m, 1H, $\left.\mathrm{C}_{\text {quino }}\right), 7.92-7.94\left(\mathrm{~m}, 1 \mathrm{H}, \mathrm{C}_{\text {quino }}\right), 8.09-8.13\left(\mathrm{~m}, 1 \mathrm{H}, \mathrm{C}_{\text {quino }}\right), 8.25-8.27\left(\mathrm{~m}, 1 \mathrm{H}, \mathrm{C}_{\text {quino }}\right)$.

${ }^{13} \mathrm{C}-\mathrm{NMR}\left(101 \mathrm{MHz}\right.$, acetone- $\left.d_{6}\right): \delta 24.10\left(\mathrm{CH}_{2}\right), 26.00\left(\mathrm{CH}_{2}\right), 26.80\left(\mathrm{CH}_{2}\right), 27.87\left(\mathrm{CH}_{2}\right)$, $32.14\left(\mathrm{CH}_{2}\right), 32.73\left(\mathrm{CH}_{2}\right), 53.10(\mathrm{SCH}), 66.44(\mathrm{CHCl}), 122.16\left(\mathrm{C}_{\text {quino }}\right), 127.03\left(\mathrm{C}_{\text {quino }}\right), 128.02$ $\left(\mathrm{C}_{\text {quino }}\right), 128.99\left(\mathrm{C}_{\text {quino }}\right), 130.77\left(\mathrm{C}_{\text {quino }}\right), 131.17\left(\mathrm{C}_{\text {quino }}\right), 131.64\left(\mathrm{C}_{\text {quino }}\right), 138.50$ ( $\left.\mathrm{C}_{\text {quino }}\right)$, 159.57 ( $\left.\mathrm{C}_{\text {quino }}\right)$.

Anal. Calcd for $\mathrm{C}_{17} \mathrm{H}_{20} \mathrm{NClS}$ : C 66.76, $\mathrm{H}$ 6.59, $\mathrm{Cl} 11.59, \mathrm{~N} 4.58, \mathrm{~S} 10.48$. Found: C 66.93, $\mathrm{H}$ 6.71, Cl 11.93, N 4.79, S 12.00 .

7a,8,9,10,11,12,13,13a-Octahydrocyclocta[4,5][1,3]thiazolo[3,2-a]quinolin-14-ium bromide (15). A solution of bromide $(0.074 \mathrm{~g}, 0.46 \mathrm{mmol})$ in methylene chloride $(5 \mathrm{~mL})$ was added dropwise to a solution of 2-mercaptoquinoline $(0.075 \mathrm{~g}, 0.46 \mathrm{mmol})$ in methylene chloride $(5 \mathrm{~mL})$, and the mixture was stirred for $15 \mathrm{~min}$ at room temperature. The obtained solution of 2-quinolinesulfenyl bromide was added dropwise to a solution of cyclooctene $(0.102 \mathrm{~g}$, $0.92 \mathrm{mmol})$ in methylene chloride $(5 \mathrm{~mL})$, and the reaction mixture was stirred for $20 \mathrm{~h}$ at room temperature. The solvent was removed by a rotary evaporator. The residue was washed with $\mathrm{CCl}_{4}$ and dried in vacuum, giving product $15(0.120 \mathrm{~g}, 77 \%$ yield $)$ as a light-yellow oil.

${ }^{1} \mathrm{H}-\mathrm{NMR}\left(400 \mathrm{MHz}, \mathrm{D}_{2} \mathrm{O}\right): \delta 1.24-1.39\left(\mathrm{~m}, 3 \mathrm{H}, \mathrm{CH}_{2}\right), 1.59-1.71\left(\mathrm{~m}, 3 \mathrm{H}, \mathrm{CH}_{2}\right), 1.81-1.91$ $\left(\mathrm{m}, 3 \mathrm{H}, \mathrm{CH}_{2}\right), 1.99-2.08\left(\mathrm{~m}, 1 \mathrm{H}, \mathrm{CH}_{2}\right), 2.11-2.25\left(\mathrm{~m}, 1 \mathrm{H}, \mathrm{CH}_{2}\right), 2.35-2.44\left(\mathrm{~m}, 1 \mathrm{H}, \mathrm{CH}_{2}\right)$, 4.61-4.67 (m 1H, SCH), 5.87-5.92 (m, 1H, NCH), 7.66-7.72 (m, 2H, C quino), 7.80-7.83 (m, $\left.1 \mathrm{H}, \mathrm{C}_{\text {quino }}\right), 7.96-8.01\left(\mathrm{~m}, 1 \mathrm{H}, \mathrm{C}_{\text {quino }}\right), 8.03-8.06\left(\mathrm{~m}, 1 \mathrm{H}, \mathrm{C}_{\text {quino }}\right), 8.50-8.52\left(\mathrm{~m}, 1 \mathrm{H}, \mathrm{C}_{\text {quino }}\right)$.

${ }^{13} \mathrm{C}-\mathrm{NMR}\left(101 \mathrm{MHz}, \mathrm{D}_{2} \mathrm{O}\right): \delta 23.20,23.76,24.10,25.66,26.11,27.75\left(\mathrm{CH}_{2}\right), 50.93(\mathrm{SCH})$, $71.74(\mathrm{NCH}), 117.64\left(\mathrm{C}_{\text {quino }}\right), 117.72\left(\mathrm{C}_{\text {quino }}\right), 126.78\left(\mathrm{C}_{\text {quino }}\right), 127.96\left(\mathrm{C}_{\text {quino }}\right), 130.37$ ( $\left.\mathrm{C}_{\text {quino }}\right)$, $134.98\left(\mathrm{C}_{\text {quino }}\right), 136.63\left(\mathrm{C}_{\text {quino }}\right), 144.54\left(\mathrm{C}_{\text {quino }}\right), 162.63\left(\mathrm{C}_{\text {quino }}\right)$.

Anal. Calcd for $\mathrm{C}_{17} \mathrm{H}_{20} \mathrm{NBrS}$ : C 58.28, H 5.75, Br 22.81, N 4.00, S 9.15. Found: C 58.61, H 6.02, Br 23.14, N 4.31, S 9.71.

\subsection{Synthesis of Compounds $\mathbf{1 6}$ and $\mathbf{1 7}$ by the Reactions of Quinolinesulfenyl Chloride $\mathbf{2}$ with Styrene and Isoeugenol}

1-Phenyl-1,2-dihydro[1,3]thiazolo[3,2-a]quinolin-10-ium chloride (16). A solution of sulfuryl chloride $(0.047 \mathrm{~g}, 0.34 \mathrm{mmol})$ in methylene chloride $(5 \mathrm{~mL})$ was added dropwise to a solution of 2-mercaptoquinoline $(0.056 \mathrm{~g}, 0.34 \mathrm{mmol})$ in methylene chloride $(5 \mathrm{~mL})$, and the mixture was stirred for $15 \mathrm{~min}$ at room temperature. The obtained solution of 2quinolinesulfenyl chloride was added dropwise to a solution of styrene $(0.072 \mathrm{~g}, 0.68 \mathrm{mmol})$ in methylene chloride $(5 \mathrm{~mL})$, and the reaction mixture was stirred for $20 \mathrm{~h}$ at room temperature. The solvent was removed by a rotary evaporator. The residue was washed with $\mathrm{CCl}_{4}$ and dried in vacuum, giving product $16(0.104 \mathrm{~g}, 100 \%$ yield) as a yellow oil.

${ }^{1} \mathrm{H}-\mathrm{NMR}\left(400 \mathrm{MHz}, \mathrm{D}_{2} \mathrm{O}\right): \delta 3.50-3.54\left(\mathrm{~m}, 1 \mathrm{H}, \mathrm{SCH}_{2}\right), 4.31-4.36\left(\mathrm{~m}, 1 \mathrm{H}, \mathrm{SCH}_{2}\right), 6.89-6.95$ (m, 2H, Ar), 6.93-6.97 (m, H, NCH), 7.04-7.12 (m, 3H, Ar), 7.40-7.44 (m, 1H, C quino), 7.49-7.56 (m, 2H, $\left.\mathrm{C}_{\text {quino }}\right), 7.78-7.82\left(\mathrm{~m}, 1 \mathrm{H}, \mathrm{C}_{\text {quino }}\right), 7.85-7.90\left(\mathrm{~m}, 1 \mathrm{H}, \mathrm{C}_{\text {quino }}\right), 8.52-8.56\left(\mathrm{~m}, 1 \mathrm{H}, \mathrm{C}_{\text {quino }}\right)$.

${ }^{13} \mathrm{C}-\mathrm{NMR}\left(101 \mathrm{MHz}, \mathrm{D}_{2} \mathrm{O}\right): \delta 37.87\left(\mathrm{SCH}_{2}\right), 71.06(\mathrm{NCH}), 118.10\left(\mathrm{C}_{\text {quino }}\right), 118.30$ (C $\left.\mathrm{C}_{\text {quino }}\right), 125.39$ (Ar), 126.73 ( $\left.\mathrm{C}_{\text {quino }}\right), 128.42$ ( $\left.\mathrm{C}_{\text {quino }}\right), 129.51$ (Ar), 129.65 (Ar), 130.47 ( $\left.\mathrm{C}_{\text {quino }}\right)$, $135.07\left(\mathrm{C}_{\text {quino }}\right), 135.21\left(\mathrm{C}_{\text {quino }}\right), 137.12(\mathrm{Ar}), 145.88\left(\mathrm{C}_{\text {quino }}\right), 166.15\left(\mathrm{C}_{\text {quino }}\right)$.

Anal. Calcd for $\mathrm{C}_{17} \mathrm{H}_{14} \mathrm{NClOS}$ : C 68.10, $\mathrm{H} 4.71, \mathrm{Cl} 11.82, \mathrm{~N} 4.67, \mathrm{~S} 10.70$. Found: $\mathrm{C}$ 68.34, H 4.97, Cl 12.12, N 4.81, S 11.20.

trans-1-(Hydroxy-3-methoxyphenyl)-2-methyl-1,2-dihydro[1,3]thiazolo[3,2-a]quinolin-10-ium chloride (17). A solution of sulfuryl chloride $(0.078 \mathrm{~g}, 0.57 \mathrm{mmol})$ in methylene chloride $(5 \mathrm{~mL})$ 
was added dropwise to a solution of 2-mercaptoquinoline $(0.093 \mathrm{~g}, 0.57 \mathrm{mmol})$ in methylene chloride $(5 \mathrm{~mL})$, and the mixture was stirred for $15 \mathrm{~min}$ at room temperature. The obtained solution of 2-quinolinesulfenyl chloride was added dropwise to a solution of isoeugenol $(0.189 \mathrm{~g}, 1.15 \mathrm{mmol})$ in methylene chloride $(5 \mathrm{~mL})$, and the reaction mixture was stirred for $20 \mathrm{~h}$ at room temperature. After filtration, the solvent was removed by a rotary evaporator, and the residue was washed with $\mathrm{CCl}_{4}$ and dried in vacuum, giving product $17(0.166 \mathrm{~g}$, $80 \%$ yield) as an orange oil.

${ }^{1} \mathrm{H}-\mathrm{NMR}\left(400 \mathrm{MHz}, \mathrm{D}_{2} \mathrm{O}\right): \delta 1.70\left(\mathrm{~d}, J 7.0 \mathrm{~Hz}, 3 \mathrm{H}, \mathrm{CH}_{3}\right), 3.76\left(\mathrm{~s}, 3 \mathrm{H}, \mathrm{O} ; \mathrm{CH}_{3}\right), 4.07-4.12$ (m, 1H, SCH), 6.21 (d, J 8.2 Hz, 1H, NCH), 6.56-6.60 (m, 1H, Ar), 6.66 (s, 1H, Ar), 6.91 (s, 1H, $\mathrm{Ar}), 7.62-7.66\left(\mathrm{~m}, 1 \mathrm{H}, \mathrm{C}_{\text {quino }}\right), 7.74-7.79\left(\mathrm{~m}, 2 \mathrm{H}, \mathrm{C}_{\text {quino }}\right), 7.93-7.96\left(\mathrm{~m}, 1 \mathrm{H}, \mathrm{C}_{\text {quino }}\right), 8.08-8.11$ $\left(\mathrm{m}, 1 \mathrm{H}, \mathrm{C}_{\text {quino }}\right), 8.72-8.75\left(\mathrm{~m}, 1 \mathrm{H}, \mathrm{C}_{\text {quino }}\right)$.

${ }^{13} \mathrm{C}-\mathrm{NMR}\left(101 \mathrm{MHz}, \mathrm{D}_{2} \mathrm{O}\right): \delta 22.38\left(\mathrm{CH}_{3}\right), 50.80(\mathrm{SCH}), 55.77\left(\mathrm{OCH}_{3}\right), 77.37(\mathrm{NCH})$, 109.61 (Ar), 115.50 (Ar), 117.48 (Ar), 118.08 ( $\left.\mathrm{C}_{\text {quino }}\right), 118.51$ ( $\left.\mathrm{C}_{\text {quino }}\right), 126.83$ ( $\left.\mathrm{C}_{\text {quino }}\right), 126.94$ (Ar), 128.42 ( $\left.\mathrm{C}_{\text {quino }}\right), 130.42\left(\mathrm{C}_{\text {quino }}\right), 134.97\left(\mathrm{C}_{\text {quino }}\right), 137.59\left(\mathrm{C}_{\text {quino }}\right), 145.78(\mathrm{Ar}), 145.86$ ( $\left.\mathrm{C}_{\text {quino }}\right), 148.07$ (Ar), $164.96\left(\mathrm{C}_{\text {quino }}\right)$.

Anal. Calcd for $\mathrm{C}_{19} \mathrm{H}_{18} \mathrm{NClO}_{2} \mathrm{~S}$ : C 63.41, $\mathrm{H}$ 5.04, Cl 9.85, N 3.89, S 8.91. Found: C 63.63, H 5.21, Cl 10.17, N 4.00, S 9.27.

\section{Conclusions}

Novel reagents 2-quinolinesulfenyl chloride and bromide have been involved in the preparation of condensed heterocyclic sulfur-nitrogen compounds. The simple and efficient method for generation of 2-quinolinesulfenyl chloride and bromide is based on the action of sulfuryl chloride or bromine on available 2-mercaptoquinoline. Regioselective synthesis of novel 2-alkyl-1,2-dihydro[1,3]thiazolo[3,2-a]quinolin-10-ium derivatives in 95-100\% yields has been developed by annulation reactions of 2-quinolinesulfenyl chloride and bromide with 1-alkenes. Condensed tetracyclic products have been obtained by the reactions of 2-quinolinesulfenyl chloride and bromide and cycloalkenes.

The reactions of cyclopentene with both 2-quinolinesulfenyl chloride and bromide at room temperature afforded condensed tetracyclic products in high yields. The reaction of 2-quinolinesulfenyl chloride with cyclooctene led to an electrophilic addition product in quantitative yield. When 2-quinolinesulfenyl bromide was involved in the reaction with cyclooctene under similar conditions, the tetracyclic condensed compound was obtained in quantitative yield.

The reactions of 2-quinolinesulfenyl chloride with styrene and natural compound isoeugenol proceeded in a regioselective manner but with opposite regiochemistry compared to the reactions of 2-quinolinesulfenyl chloride with terminal alkenes. The electrophilic addition of the sulfur atom of 2-quinolinesulfenyl chloride occurred to the $\beta$-carbon atom of the double bond of styrene and isoeugenol in a Markovnikov fashion.

The reaction of 2-quinolinesulfenyl chloride with terminal alkenes was supposed to proceed via intermediate thiiranium cation, and nucleophilic attack of the nitrogen atom of the quinoline ring occurred at the least substituted carbon atom of thiiranium ion, leading to the formation of condensed products in an anti-Markovnikov fashion.

The obtained condensed sulfur-nitrogen heterocycles are novel water-soluble functionalized compounds with potential biological activity.

Supplementary Materials: The following are available online. Supporting Information file: examples of ${ }^{1} \mathrm{H}$ - and ${ }^{13} \mathrm{C}-\mathrm{NMR}$ spectra of the obtained compounds.

Author Contributions: Conceptualization and the paper preparation, V.A.P.; methodology and research experiments, R.S.I.; data curation and supervision, S.V.A. All authors have read and agreed to the published version of the manuscript.

Funding: This research received no external funding.

Institutional Review Board Statement: Not applicable.

Informed Consent Statement: Not applicable. 
Data Availability Statement: Data is available in this article and Supplementary Materials.

Acknowledgments: The authors thank Baikal Analytical Centre SB RAS for providing the instrumental equipment for structural investigations.

Conflicts of Interest: The authors declare no conflict of interest.

Sample Availability: Samples of the compounds are not available from the authors.

\section{References}

1. Gomtsyan, A. Heterocycles in drugs and drug discovery. Chem. Heterocyclic Compd. 2012, 48, 7-10. [CrossRef]

2. Feng, M.; Tang, B.; Liang, S.H.; Jiang, X. Sulfur Containing Scaffolds in Drugs: Synthesis and Application in Medicinal Chemistry. Curr. Top. Med. Chem. 2016, 16, 1200-1216. [CrossRef] [PubMed]

3. Weyesa, A.; Mulugeta, E. Recent advances in the synthesis of biologically and pharmaceutically active quinoline and its analogues: A review. RSC Adv. 2020, 10, 20784-20793. [CrossRef]

4. Chung, P.-Y.; Bian, Z.-X.; Pun, H.-Y.; Chan, D.; Chan, A.S.-C.; Chui, C.-H.; Tang, J.C.-O.; Lam, K.-H. Recent advances in research of natural and synthetic bioactive quinolines. Future Med. Chem. 2015, 7, 947-967. [CrossRef] [PubMed]

5. Kumar, S.; Bawa, S.; Gupta, H. Biological activities of quinoline derivatives. Mini Rev. Med. Chem. 2009, 9, 1648-1654. [CrossRef] [PubMed]

6. Raut, K.; Thombare, R.; Zagade, P.; Kumbhar, N. Different biological activities of quinoline. World J. Pharm. Res. 2020, 9, 674-689.

7. Abass, M.; Alzandi, A.R.A.; Hassan, M.M.; Mohamed, N. Recent Advances on Diversity Oriented Heterocycle Synthesis of Fused Quinolines and Its Biological Evaluation. Polycycl. Arom. Comp. 2020, 40, 1710856. [CrossRef]

8. Shiro, T.; Fukaya, T.; Tobe, M. The chemistry and biological activity of heterocycle-fused quinolinone derivatives: A review. Eur. J. Med. Chem. 2015, 97, 397-408. [CrossRef]

9. Vitaku, E.; Smith, D.T.; Njardarson, J.T. Analysis of the Structural Diversity, Substitution Patterns, and Frequency of Nitrogen Heterocycles among U.S. FDA Approved Pharmaceuticals. J. Med. Chem. 2014, 57, 10257-10274. [CrossRef]

10. McKee, D.L.; Sternberg, A.; Stange, U.; Laufer, S.; Naujokat, C. Candidate drugs against SARS-CoV-2 and COVID-19. Pharmacol. Res. 2020, 157, 104859. [CrossRef]

11. Wagman, A.S.; Moser, H.E.; Mcenroe, G.A.; Aggen, J.B.; Linsell, M.S.; Goldblum, A.A.; Griffin, J.H. Fluoroquinolone Analogs as Antibacterial Agents and Their Preparation and Use in the Treatment of Bacterial Infection. Patent WO 2011031745, 9 September 2009.

12. Dinakaran, M.; Senthilkumar, P.; Yogeeswari, P.; China, A.; Nagaraja, V.; Sriram, D. Synthesis, antimycobacterial activities and phototoxic evaluation of 5H-thiazolo[3,2-a]quinoline-4-carboxylic acid derivatives. Med. Chem. 2008, 4, 482-491. [CrossRef]

13. Potemkin, V.A.; Grishina, M.A.; Belik, A.V.; Chupakhin, O.N. Quantitative relationship between structure and antibacterial activity of quinolone derivatives. Pharmaceut. Chem. J. 2002, 36, 22-25. [CrossRef]

14. Ozaki, M.; Segawa, J.; Kitano, M.; Tomii, Y.; Honmura, T.; Matsuda, M.; Kise, M.; Nishino, T. Structure-antibacterial activity and cytotoxicity relationships of thiazolo and thiazetoquinolone derivatives. Biolog. Pharm. Bull. 1996, 19, 1457-1462. [CrossRef] [PubMed]

15. Klopman, G.; Wang, S.; Jacobs, M.R.; Bajaksouzian, S.; Edmonds, K.; Ellner, J.J. Anti-mycobacterium avium activity of quinolones: In vitro activities. Antimicrob. Agents Chemother. 1993, 37, 1799-1806. [CrossRef]

16. Segawa, J.; Kitano, M.; Kazuno, K.; Tsuda, M.; Shirahase, I.; Ozaki, M.; Matsuda, M.; Kise, M. Studies on pyridonecarboxylic acids. 2. Synthesis and antibacterial activity of 8-substituted 7-fluoro-5-oxo-5H-thiazolo[3,2-a]quinoline-4-carboxylic acids. J. Heterocycl. Chem. 1992, 29, 1117-1123. [CrossRef]

17. Ohta, M.; Koga, H. Three-dimensional structure-activity relationships and receptor mapping of N1-substituents of quinolone antibacterials. J. Med. Chem. 1991, 34, 131-139. [CrossRef]

18. Sauter, F.; Jordis, U.; Rudolf, M.; Wieser, J.; Baumann, K. Preparation of Bicyclic Substituted Quinolonecarboxylic Acid Derivatives, Useful as Antibacterial Pharmaceuticals. Patent DE 3721745, 1 July 1987.

19. Sauter, F.; Jordis, U.; Rudolf, M.; Wieser, J.; Baumann, K. 4-Quinolone-3-carboxylic Acid Derivatives, Process for Their Synthesis and Pharmaceutical Preparations Containing Them. Patent EP 251308, 1 July 1987.

20. Enomoto, H.; Kise, M.; Ozaki, M.; Kitano, M.; Morita, I. Preparation and Formulation of Quinolonecarboxylic Acid Derivatives as Antibacterials. U.S. Patent 4659734, 15 August 1983.

21. Mich, T.F.; Sanchez, J.P. Antibacterial Thiazoloquinoline- and Thiazolonaphthyridinecarboxylates. U.S. Patent 4550104,20 July 1984.

22. Hosomi, J.; Asahina, Y.; Suzue, S. Preparation of Thiazoloquinolonecarboxylic Acid Derivatives and Their Pharmaceutical Compositions as Antitumor Agents. Patent WO 8912055, 7 June 1989.

23. Hromas, R.; Leitao, A.; Oprea, T.I.; Sklar, L.A.; Williamson, E.A.; Wray, J. Metnase and Intnase Inhibitors and Their Use in Treating Cancer. Patent WO 2010114919, 31 March 2010.

24. Nakayama, K.; Takeda, Y.; Haginoya, N.; Naito, H.; Mochizuki, A.; Saitou, M.; Odagiri, T.; Shibata, Y.; Tsunemi, T.; Shimazaki, N. Preparation of Tricyclic 5-Aminoquinolone Derivatives as Glycogen Synthase Kinase 3 Inhibitors. Patent WO 2014003098, 27 June 2013.

25. Tsumiki, M.; Miki, I.; Sato, S.; Shimada, J.; Suzuki, F. Preparation of Quinolones as Allergy and Cancer Metastasis Inhibitors and Anti-Inflammatory Drugs. Patent JP 09278780, 9 April 1996.

26. Nenortas, E.; Kulikowicz, T.; Burri, C.; Shapiro, T.A. Antitrypanosomal activities of fluoroquinolones with pyrrolidinyl substitutions. Antimicrob. Agents Chemother. 2003, 47, 3015-3017. [CrossRef] [PubMed] 
27. Wakita, K.; Shimazaki, N.; Iwasaki, S. Combination of gsk3 Inhibitor and Anti-DR5 Antibody for Cancer Therapy. Patent WO 2014050779, 24 September 2013.

28. Musalov, M.V.; Yakimov, V.A.; Potapov, V.A.; Amosova, S.V.; Borodina, T.N.; Zinchenko, S.V. A novel methodology for the synthesis of condensed selenium heterocycles based on the annulation and annulation-methoxylation reactions of selenium dihalides. New J. Chem. 2019, 43, 18476-18483. [CrossRef]

29. Musalov, M.V.; Potapov, V.A. Selenium dihalides: New possibilities for the synthesis of selenium-containing heterocycles. Chem. Heterocycl. Compd. 2017, 53, 150-152. [CrossRef]

30. Accurso, A.A.; Cho, S.-H.; Amin, A.; Potapov, V.A.; Amosova, S.V.; Finn, M.G. Thia-, Aza-, and Selena[3.3.1]bicyclononane Dichlorides: Rates vs Internal Nucleophile in Anchimeric Assistance. J. Org. Chem. 2011, 76, 4392-4395. [CrossRef]

31. Potapov, V.A.; Amosova, S.V.; Abramova, E.V.; Lyssenko, K.A.; Musalov, M.V.; Finn, M.G. Transannular Addition of Selenium Dichloride and Dibromide to 1,5-Cyclooctadiene: Synthesis of 2,6-Dihalo-9-selenabicyclo[3.3.1]nonanes and Their Complexes with Selenium Dihalides. New J. Chem. 2015, 39, 8055-8059. [CrossRef]

32. Potapov, V.A.; Amosova, S.V.; Kashik, A.S. Reactions of selenium and tellurium metals with phenylacetylene in 3-phase catalytical systems. Tetrahedron Lett. 1989, 30, 613-616. [CrossRef]

33. Potapov, V.A.; Volkova, K.A.; Penzik, M.V.; Albanov, A.I.; Amosova, S.V. Reaction of selenium dichloride with divinyl selenide. Russ. J. Org. Chem. 2008, 44, 1556-1557. [CrossRef]

34. Potapov, V.A.; Malinovich, D.A.; Amosova, S.V.; Rusakov, Y.Y.; Bhasin, K.K. Reaction of 2-pyridylselenenyl bromide with divinyl selenide. Chem. Heterocycl. Comp. 2012, 48, 1129-1131. [CrossRef]

35. Potapov, V.A.; Musalova, M.V.; Ishigeev, R.S.; Musalov, M.V.; Panov, V.A.; Khabibulina, A.G.; Amosova, S.V.; Bhasin, K.K. Efficient and selective syntheses of novel unsaturated chalcogen-containing pyridine derivatives. Tetrahedron Lett. 2016, 57, 5341-5343. [CrossRef]

36. Potapov, V.A.; Ishigeev, R.S.; Amosova, S.V.; Borodina, T.N. Synthesis of a novel family of water-soluble 2H,3H-[1,3]thia- and -selenazolo[3,2-a]pyridin-4-ium heterocycles by annulation reactions. Tetrahedron Lett. 2019, 60, 475-479. [CrossRef]

37. Potapov, V.A.; Ishigeev, R.S.; Amosova, S.V. Synthesis of 3-(2-oxopyrrolidin-1-yl)-2H,3H-[1,3]selenazolo[3,2-a]pyridin-4-ium chloride. Russ. J. Org. Chem. 2017, 53, 1604-1605. [CrossRef]

38. Potapov, V.A.; Ishigeev, R.S.; Amosova, S.V. Regioselective Reaction of Pyridine-2-Sulfenyl Chloride with Isoeugenole. Russ. J. Org. Chem. 2018, 54, 1262-1263.

39. Potapov, V.A.; Ishigeev, R.S.; Shkurchenko, I.V.; Zinchenko, S.V.; Amosova, S.V. Natural compounds and their structural analogs in regio- and stereoselective synthesis of new families of water-soluble $2 \mathrm{H}, 3 \mathrm{H}$-[1,3]thia- and -selenazolo[3,2-a]pyridin-4-ium heterocycles by annulation reactions. Molecules 2020, 25, 376. [CrossRef]

40. Potapov, V.A.; Ishigeev, R.S.; Amosova, S.V. Efficient Regioselective Synthesis of Novel Water-Soluble 2H,3H-[1,4]thiazino[2,3,4ij]quinolin-4-ium Derivatives by Annulation Reactions of 8-quinolinesulfenyl Halides. Molecules 2021, 26, 1116. [CrossRef]

41. Ishigeev, R.S.; Potapov, V.A.; Skurchenko, I.V.; Khabibulina, A.G.; Amosova, S.V. Chemistry of Synthesis of new polycyclic compounds via the reaction of quinoline-8-sulfenyl halides with cyclic alkenes. Chem. Heterocycl. Comp. 2021, 57, 314-319. [CrossRef]

42. Samuilov, Y.D.; Gainullin, V.I.; Solov'eva, S.E.; Konovalov, A.I. Reactivity of styrenes toward electrophilic addition of phenylsulfenyl chloride. Zhurnal Organicheskoi Khimii 1988, 24, 795-803. (In Russian) (Chem. Abstr. 1988, 109, 189586).

43. Koval', I.V. Sylfenyl chlorides in organic synthesis. Russ. Chem. Rev. 1995, 64, 731-751. [CrossRef]

44. Rasteikiene, L.; Greiciute, D.; Lin'kova, M.G.; Knunyants, I.L. The Addition of Sulphenyl Chlorides to Unsaturated Compounds. Russ. Chem. Rev. 1977, 46, 548-564. [CrossRef]

45. Smit, V.A.; Zefirov, N.S.; Bodrikov, I.V.; Krimer, M.Z. Episulfonium ions: Myth and reality. Acc. Chem. Res. 1979, 12, 282-288. [CrossRef]

46. Abu-yousef, I.A.; Harpp, D.N. New Sulfenyl Chloride Chemistry: Synthesis, Reactions and Mechanisms toward Carbon-Carbon Double Bonds. Sulfur Rep. 2003, 24, 255-282. [CrossRef]

47. Denmark, S.E.; Vogler, T. Synthesis and Reactivity of Enantiomerically Enriched Thiiranium Ions. Chem. Eur. J. 2009, 15, 11737-11745. [CrossRef]

48. Denmark, S.E.; Collins, W.R.; Cullen, M.D. Observation of Direct Sulfenium and Selenenium Group Transfer from Thiiranium and Seleniranium Ions to Alkenes. J. Am. Chem. Soc. 2009, 131, 3490-3492. [CrossRef] [PubMed]

49. Soloshonok, V.A.; Nelson, D.J. Alkene selenenylation: A comprehensive analysis of relative reactivities, stereochemistry and asymmetric induction, and their comparisons with sulfenylation. Beilstein J. Org. Chem. 2011, 7, 744-758. [CrossRef]

50. Mueller, W.H.; Butler, P.E. Orientational effects in the addition of acetylthiosulfenyl chloride to olefins. J. Org. Chem. 1967, 32, 2925-2929. [CrossRef]

51. Kharasch, N.; Potempa, S.J.; Wehrmeister, H.L. The sulfenic acids and their derivatives. Chem. Rev. 1946, 39, 269-332. [CrossRef] [PubMed]

52. Koval', I.V. S-Cationoid reagents in organic synthesis. Russ. Chem. Rev. 1995, 64, 141-166. [CrossRef]

53. Mueller, W.H.; Butler, P.E. Reaction of sulfenyl chlorides with allene. J. Org. Chem. 1968, 33, 1533-1537. [CrossRef]

54. Huang, J.; Hu, G.; An, S.; Chen, D.; Li, M.; Li, P. Synthesis of N-Alkylpyridin-4-ones and Thiazolo[3,2-a]pyridin-5-ones through Pummerer-Type Reactions. J. Org. Chem. 2019, 84, 9758-9769. [CrossRef]

55. Chorell, E.; Das, P.; Almqvist, F. Diverse Functionalization of Thiazolo Ring-Fused 2-Pyridones. J. Org. Chem. 2007, 72, 4917-4924. [CrossRef] [PubMed] 